\title{
THE VALLEY-FILL DEPOSITS OF THE KLODNICA RIVER (SOUTHERN POLAND): ENVIRONMENTAL DRIVERS OF FACIES CHANGES FROM THE LATE VISTULIAN THROUGH THE HOLOCENE
}

\author{
KRZYSZTOF J. WÓJCICKI \\ Department of Quaternary Palaeogeography and Palaeoecology, Faculty of Earth Sciences, \\ University of Silesia, Będzińska 60, 41-200 Sosnowiec, Poland
}

\begin{abstract}
Lithological analyses and radiocarbon dating were used to elucidate the patterns and controls of Late Quaternary valley floor development of the Kłodnica River, the Upper Odra Basin. The research results were discussed with data obtained from valleys of rivers draining piedmont basins and highlands of southern Poland. In consequence, five stages of morpho-sedimentary evolution of the Kłodnica valley were distinguished. In the Late Vistulian a large-scale deposition of channel alluvium took place in the conditions of high river discharges. This sedimentary style probably still existed in the Early Pre-Boreal as long as open grass communities survived in the Kłodnica catchment. The next phase, in the Late Pre-Boreal and Boreal, is characterized by a significant increase in accumulation rate of biochemical facies.. The considerable restriction of minerogenic deposition was connected with widespread of forest and gradual limitation of the river discharges. The third stage began at the decline of the Boreal and was defined by decrease of accumulation rate or even biogenic accumulation break. Synchronously, periodic increases of fluvial activity were noticed in the form of cutoffs of meander loops and overbank deposition in oxbows. The beginning of the fourth period took place not earlier than in the Early Sub-Boreal. This stage was distinguished by renewed peat growth/increase in biochemical accumulation rate and periodic increase in alluviation, generally taking place in the conditions of low channel-forming flows. The latest phase (from the Middle SubAtlantic till now) is characterized by common initiation of slope deposition and a rapid increase in fluvial sedimentation, especially overbank and tributary fan facies. An increase in minerogenic deposition occurred in response to human impact, which became more significant from the Roman Period and occurred on a large scale from the early Middle Ages. Older settlement phases, including intense settlement from the Hallstatt Period, were not clearly recorded in the Kłodnica valley fill.
\end{abstract}

Keywords: Fluvial system; Alluviation; Climate change; Human impact; Geochronology; Temperate zone

\section{INTRODUCTION}

Many years of research on valley fills architecture, conducted in different climatic zones, led to the identification of numerous depositional environments and corresponding facies of deposits (Table 1). Application of methods of absolute chronology allowed establishing that accumulation rate of each facies of deposits was varied through time in response to climate change and human impact. Palaeogeographical reconstructions based on

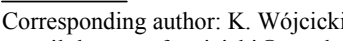

e-mail: krzysztof.wojcicki@us.edu.pl

ISSN 1897-1695 (online), 1733-8387 (print) @ 2010 GADAM Centre, Institute of Physics, Silesian University of Technology.

All rights reserved. deposit accretion through time focus usually on a specified genetic group of sediments considered as an indicator of environmental changes. The fluvial sediments, especially overbank facies arouse main interest. On the basis of that, flooding episodes connected with climate deterioration or deforestation for arable farming are reconstructed (e.g. Kalicki, 1996; Starkel, 2001; Benito et al., 2003; Lewin et al., 2005 and Macklin et al., 2006). Numerous studies are also devoted to channel facies in order to identify periods of increase in fluvial activity leading to avulsions and forming new meander belts (e.g. Törnqvist, 1994; Starkel et al., 1999; Berendsen and Stouthamer, 2002; Morozova and Smith, 2003 and Kalicki, 2006). Magnitudes of biochemical accumulation 
Table 1. Facies of valley-fill deposits depending on a zone of the fluvial system.

\begin{tabular}{|c|c|c|}
\hline $\begin{array}{l}\text { Zone of the } \\
\text { fluvial system }\end{array}$ & Main types of facies depending on depositional process or environment & Selected references \\
\hline $\begin{array}{l}\text { Sediment source- } \\
\text { area (especially in } \\
\text { mountain areas) }\end{array}$ & 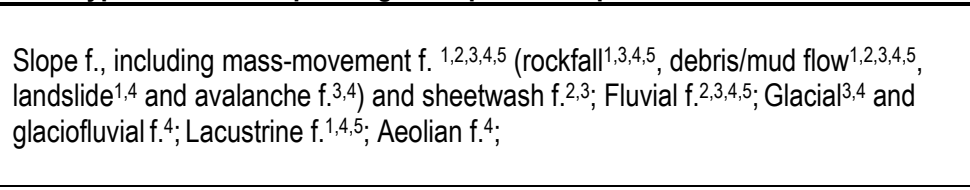 & $\begin{array}{l}{ }^{1} \text { Crouzet et al., 1999; } \\
{ }^{2} \text { Holmes et al., 2003; } \\
{ }^{3} \text { Schrott et al., 2003; } \\
{ }^{4} \text { Kamp et al., 2004; } \\
{ }^{5} \text { Friele et al., 2005; }\end{array}$ \\
\hline Transfer zone & 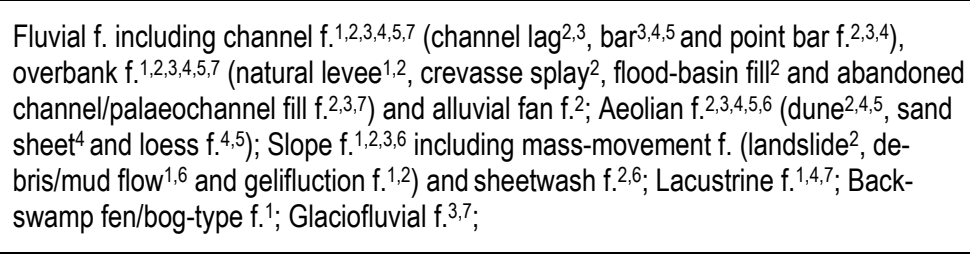 & $\begin{array}{l}{ }^{1} \text { Rose et al., 1980; } \\
{ }^{2} \text { Alexandrowicz et al., 1981; } \\
{ }^{3} \text { Koutaniemi, 1987; } \\
{ }^{4} \text { Ashley and Hamilton, 1993; } \\
{ }^{5} \text { Malik et al., 1999; } \\
{ }^{6} \text { Melis and Acworth, 2001; } \\
{ }^{7} \text { Matoshko et al., 2002; }\end{array}$ \\
\hline Area of deposition & 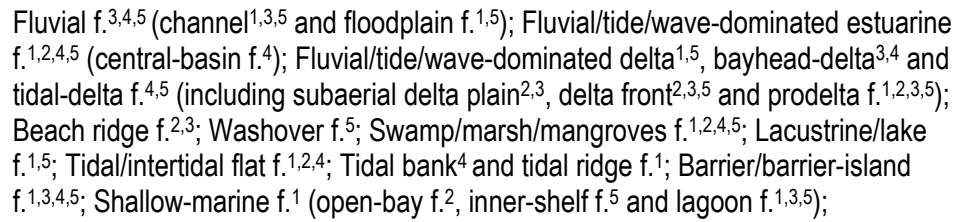 & $\begin{array}{l}1 \text { Li et al., 2002; } \\
2 \text { Ta et al., 2002; } \\
{ }^{3} \text { Bhattacharya and Giosan, 2003; } \\
{ }^{4} \text { Heap et al., 2004; } \\
{ }^{5} \text { Aguzzi et al., 2007; }\end{array}$ \\
\hline
\end{tabular}

and especially peat accumulation rate are treated as proxy indicators of groundwater table changes within valley bottoms (e.g. Koutaniemi, 1987; Rybníček and Rybníčkova, 1987; Ralska-Jasiewiczowa and Starkel, 1988 and Bohncke and Vandenberghe, 1991). Besides, they are generally related to the periods of stability of morphosedimentary evolution due to climate improvement or a low level of human activity (e.g. Wasylikowa et al., 1985 and Macaire et al., 2006). The calculation of coastal marshes sedimentation rates plays an important role in reconstruction of relative sea-level changes (e.g. White et al. 2002 and Nikitina et al., 2003). The presence of aeolian facies may prove the periods of arid climate (e.g. Malik et al., 1999; Holliday, 2000 and Melis and Acworth, 2001).

The aim of this paper is to establish chronology of sediments building Late Vistulian and Holocene valleyfill of the Kłodnica River. Obtained for the Kłodnica valley model of sedimentation style changes under the influence of the environmental factors was compared with data obtained from valley fills of rivers draining piedmont basins and highlands of southern Poland. Common features of distinguished fluvial systems are: (1) the location beyond range of Scandinavian Ice Sheet in the periglacial zone of the last glaciation, (2) the drainage of areas with domination of loose Quaternary deposits including those with major loess participation, (3) the gradient of the main river characteristic for highland rivers.

\section{REGIONAL SETTING}

The Kłodnica drainage basin, with the area of 1084.8 $\mathrm{km}^{2}$, occupies the Silesian Upland and the Racibórz Basin, southern Poland (Fig. 1 A and B). The Kłodnica River is $75.3 \mathrm{~km}$ long with an average gradient of 1.82 $\mathrm{m} / \mathrm{km}$. It was a meandering river before regulation, in all probability with an equable hydrological regime. Present flow fluctuations (Fig. 1 B1) are probably smaller than in the past, which is connected with the construction of dammed reservoirs (Dzierżno Duże, Dzierżno Małe, Pławniowice) as well as water utilization for the Gliwice Canal requirements (Absalon et al., 1996). The Kłodnica River drains areas with domination of glacial and fluvioglacial deposits of the Odranian (=Saalian) Glaciation and - in the investigated, lower part of the catchment area - also Vistulian loesses (Fig. 1 B2).

The studies were conducted in the lower course of the valley, where the Kłodnica River flows through glacial and outwash plains (Fig. 1 B3). According to Schumm's (1977) classification, the analysed reach of the valley belongs to transfer zone of the fluvial system. The valley bottom is relatively broad there $(800-1000 \mathrm{~m})$ and has a smooth longitudinal profile with a gentle gradient (about $1 \mathrm{~m} / \mathrm{km}$ ). Late Vistulian and Holocene deposits, which were the focus of attention, are located on the whole width of the valley bottom, whereas the older Pleistocene terraces do not appear. Exact investigations of the Kłodnica valley fill were possible thanks to sand exploitation in Dzierżno in the middle course of the valley. As a result, the structure of valley fill was exposed and described by Jahn (1955). The valley is cut out in marine deposits of Miocene age and thickness of valley-fill deposits reach approximately $20 \mathrm{~m}$ (Fig. 1 C). The lowest unit within the valley fill is composed of sands and gravels with domination of local limestone and dolomite and admixture of glacial crystalline rocks. On the top of the layer there are huge Scandinavian boulders that are considered as the remains of moraine of the Odranian ice sheet. Above, there is a two-metre thick series of cryogenically disturbed fine-grained sands and silts containing Pleistocene mammal bones, e.g. probably the remains of the Steppe mammoth (Mammuthus trogontherii) among them. These sediments are interpreted as swampy deposits of the valley bottom which were formed with participation of solifluction flows during the Vistulian. Basic series of deposits with a thickness reaching $18 \mathrm{~m}$ present horizontally bedded homogenous sands with cryo- 

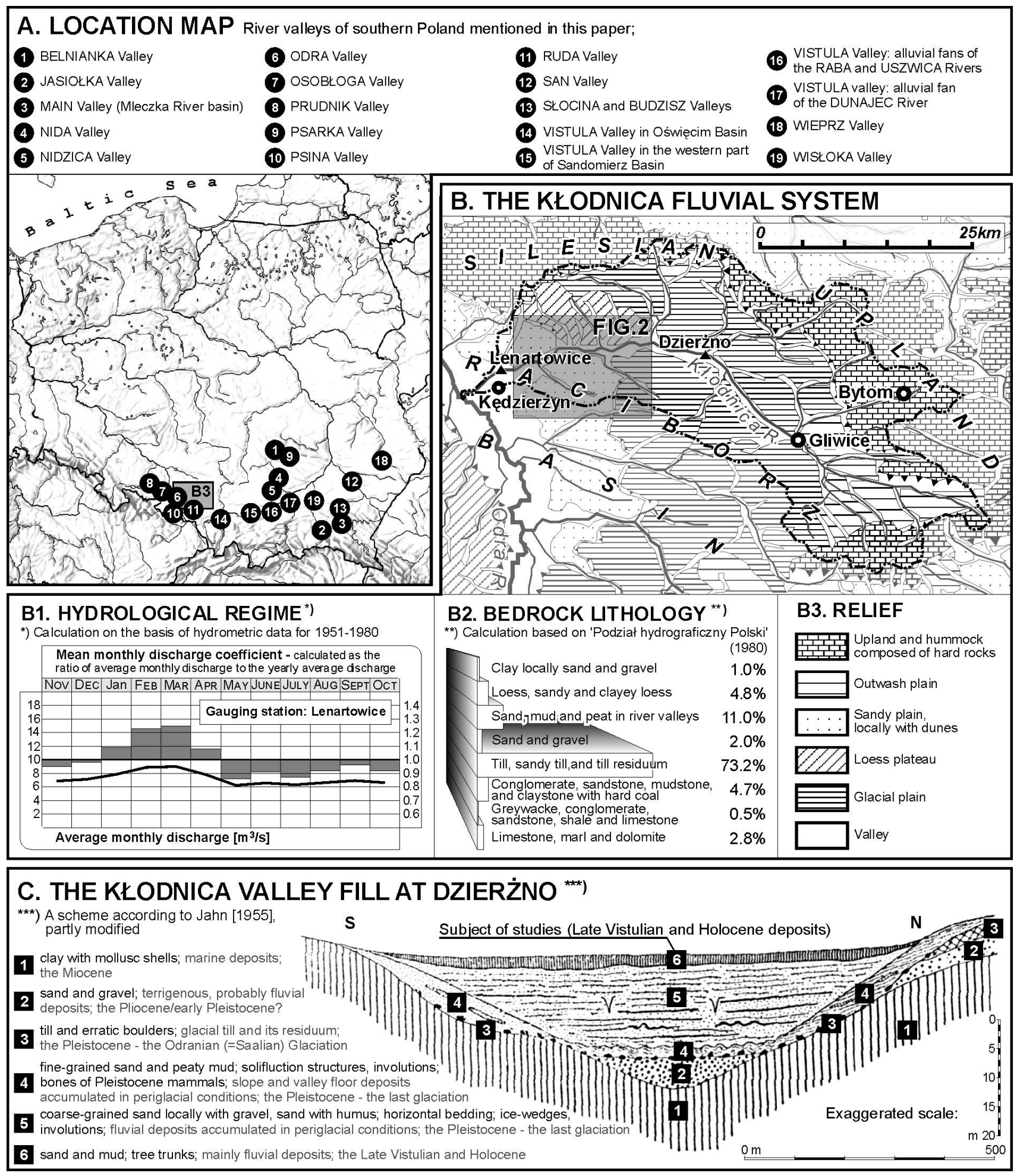

Fig. 1. Location of the study area $(A)$, characteristic of the Kłodnica River and its drainage basin (B) and lithology of the Kłodnica valley fill (C).

turbation structures. These fluvial deposits were formed during the last glaciation in conditions of more humid, still periglacial climate though. The highest layer contains grey, fine-grained sands and silts with tree trunks and peat lens. The thickness of that unit is changeable, but does not exceed 3m. Jahn (1955) attributed these sediments to the Holocene. Current research showed that these are deposits of a meandering river system formed in the Late Vistulian and Holocene. They are the objective of the investigation presented in this paper.

\section{MATERIALS AND METHODS}

Facies analysis of the Kłodnica valley fill is based on the examination of 16 sequences of deposits (Fig. 2). The exposures and the cores were situated within varying in 


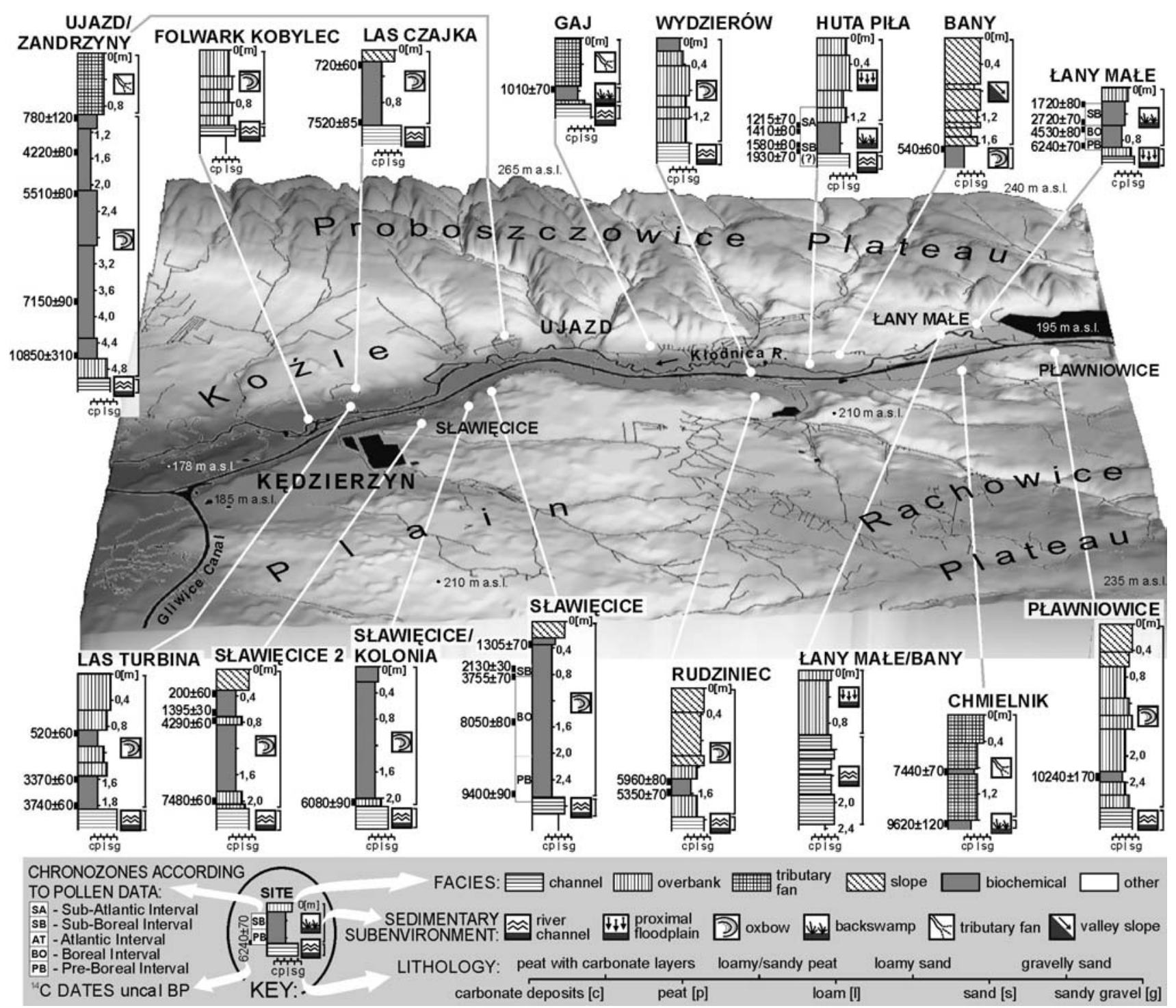

Fig. 2. Lithostratigraphy and genetic interpretation of the Kłodnica valley-fill deposits.

age fragments of the valley bottom and the analysed sequences represent the series of deposits accumulated within diverse sedimentary environment. Nevertheless, most drills were located within oxbow fills where local conditions favoured sedimentation and preservation of deposits (see Lewin and Macklin, 2003). Furthermore biogenic deposits, which appear there, enabled dating of the recorded events (Wójcicki, 2006). In order to classify deposits to individual facies lithological features of sediments were analysed and morphogenesis of landforms, composed of them, was defined (Wójcicki and Nita, 2004 and Wójcicki, 2006). Depending on the place of deposition, within fluvial facies assemblage, channel and overbank facies were distinguished (Fig. 3). Deposits of alluvial fans located at the mouth of perennial streams as well as deposits of proluvial fans developed at the mouth of ephemeral streams to the main valley were numbered among tributary fan facies. The term 'slope facies' is used in this paper for deposits accumulated by massmovement processes or sheetwash. Authogenic deposits connected with natural depression of floodplain (e.g. peat, carbonate sediments) were specified with one common term 'biochemical facies'.

Geochronology of deposits was recognized on the basis of $39{ }^{14} \mathrm{C}$ datings made in Kiev, Gliwice and Poznań Radiocarbon Laboratories. The following principles were assumed at the interpretation of obtained radiocarbon dates (see Starkel et al., 2006): (1) a sample collected within dating layer $\rightarrow$ obtained date corresponding with age of accumulation; (2) a sample collected from the top of underlying deposits $\rightarrow$ dating layer younger than obtained date; (3) a sample collected from the base of overlying deposits $\rightarrow$ dating layer older than obtained date. In the case of palaeosols a possibility of long-term break in sedimentation of deposits was taken into consideration (see Bluszcz et al., 2007). Dating both humic-rich horizons and overlying layers at the Łany Małe, Sławięcice and Sławięcice 2 sites confirmed the occurrence of hiatuses lasting even a few thousand years. The other problem was an interpretation of dating results of peat samples containing organic remains of various ages. Intrusive components (roots of trees, reeds and sedges) appear in 
deposits collected at the Łany Małe, Sławięcice, Sławięcice 2, Sławięcice Kolonia and Las Czajka sites. 'Contamination' by younger organic matter had undoubtedly negative influence on dating results especially for shallow sequences of deposits (at the Łany Małe and Las
Czajka sites) constantly remaining within a range of modern roots.

In the cases of the Lany Małe, Huta Piła and Sławięcice sites, radiocarbon chronology was supported by palynological analysis (Nita and Wójcicki, 2005).

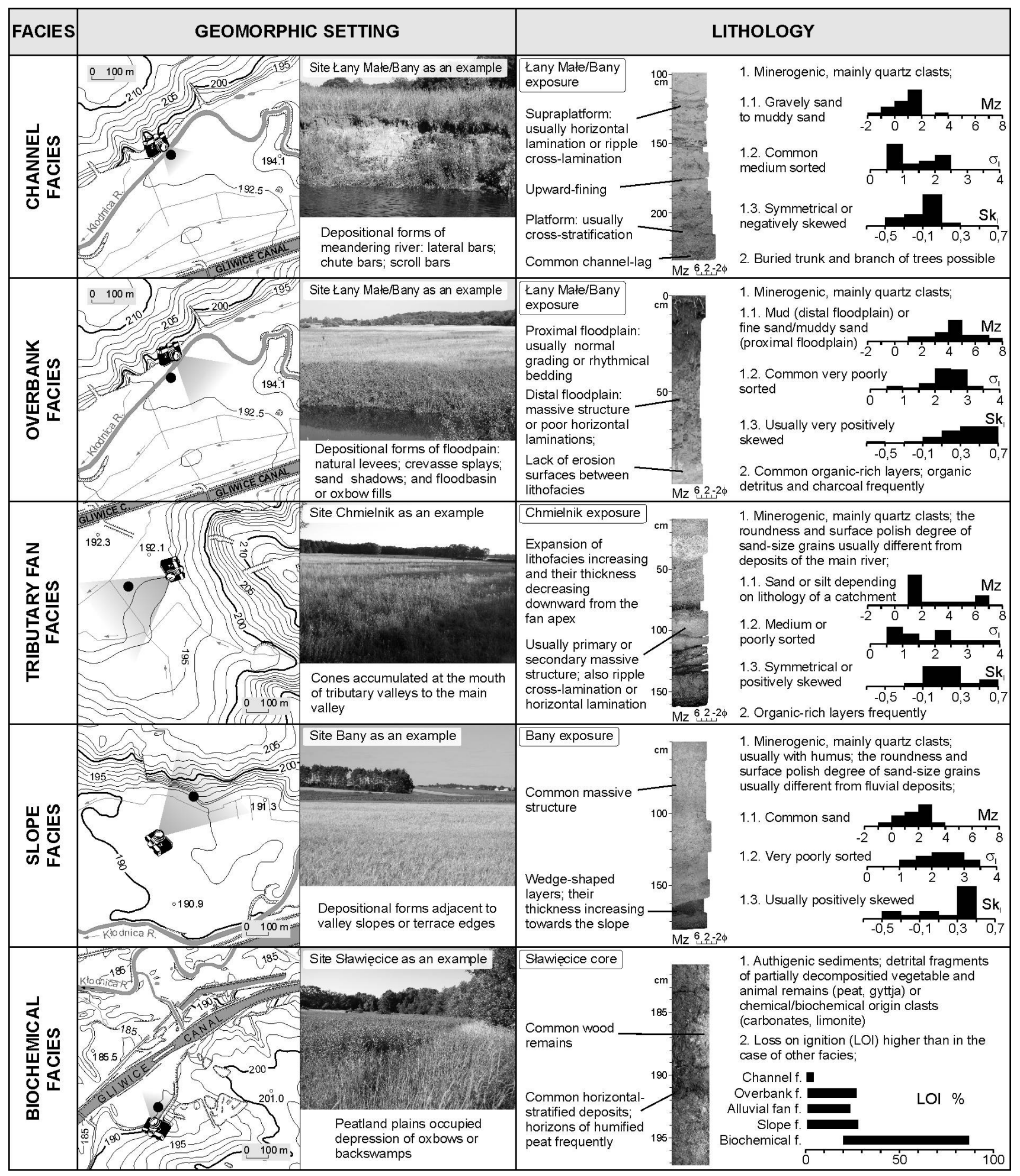

Fig. 3. Geomorphic situation and lithological characteristic of the Kłodnica valley-fill facies. Grain-size distribution and loss on ignition calculated for deposits from the Pławniowice, Łany Małe, Chmielnik, Łany Małe/Bany, Bany, Huta Piła, Wydzierów, Ujazd/Zandrzyny, Sławięcice and Las Czajka sites. 
Presence of coal clasts connected with coal mining in the upper part of the Kłodnica River catchment allowed to dating of overbank deposition at the Wydzierów and Folwark Kobylec sites on the last two centuries (see Rutkowski, 1987 and Klimek, 1999).

\section{RESULTS AND DISCUSSION}

Chronology of Late Vistulian and Holocene deposits infilling the Kłodnica valley and other valleys of southern Poland

\section{Channel facies}

The channel deposits of a sinuous river are basic facies building of Late-Vistulian and Holocene fill of the Kłodnica valley. In the axis of the valley they overlie Vistulian sands and gravels of a braided river (Jahn, 1955); while in the marginal zone of the valley bottom they were accumulated directly on the surface of Miocene marine loams. The beginning of accumulation of sinuousriver deposits in the Kłodnica valley took place in the Allerød at the latest, as point-bar deposits at the Ujazd/Zandrzyny site are older than $10850 \pm 310{ }^{14} \mathrm{C}$ yr BP (Gd-10821) (see Fig. 2).
The analysis of hydraulic geometry of the Kłodnica palaeomeanders (Fig. 4) allows to assume that the highest accumulation rate of channel deposits took place in the Late Vistulian. At that time, river channel was characterized by high value of width and meander wavelength and, therefore, radius of meander curvature correlated with the latter. According to Schumm's (1968) formula, it could be linked with intensive bed-material load. The largest as well as the oldest Kłodnica palaeomeanders are characterized by curvature radius $\mathrm{Rm}=235-280 \mathrm{~m}$, channel width $\mathrm{w}=50-66 \mathrm{~m}$ and width-depth ratio $\mathrm{w} / \mathrm{d}=21.3-22.7$. Palaeomeander at the Ujazd/Zandrzyny site, which belongs to forms of that size, according to radiocarbon dating was cut off at the beginning of the Younger Dryas at the latest. At the decline of the Late Vistulian some palaeomeanders could have been much smaller like abandoned channel at the Pławniowice site $(\mathrm{Rm}=135 \mathrm{~m}, \mathrm{w}=20 \mathrm{~m}$, $\mathrm{w} / \mathrm{d}=12.5)$. Nevertheless, in the older part of the PreBoreal meanders were probably still significantly larger than younger Holocene forms. For example, parameters of hydraulic geometry of palaeomeander at the Sławięcice site amount to $\mathrm{Rm}=180 \mathrm{~m}, \mathrm{w}=36 \mathrm{~m}$, $\mathrm{w} / \mathrm{d}=13.8$. Pollen analysis shows that sandy alluvium underlying peat at that site was deposited in the Early Pre-Boreal (Nita and Wójcicki, 2005). Lateglacial large

\section{KLODNICA RIVER}

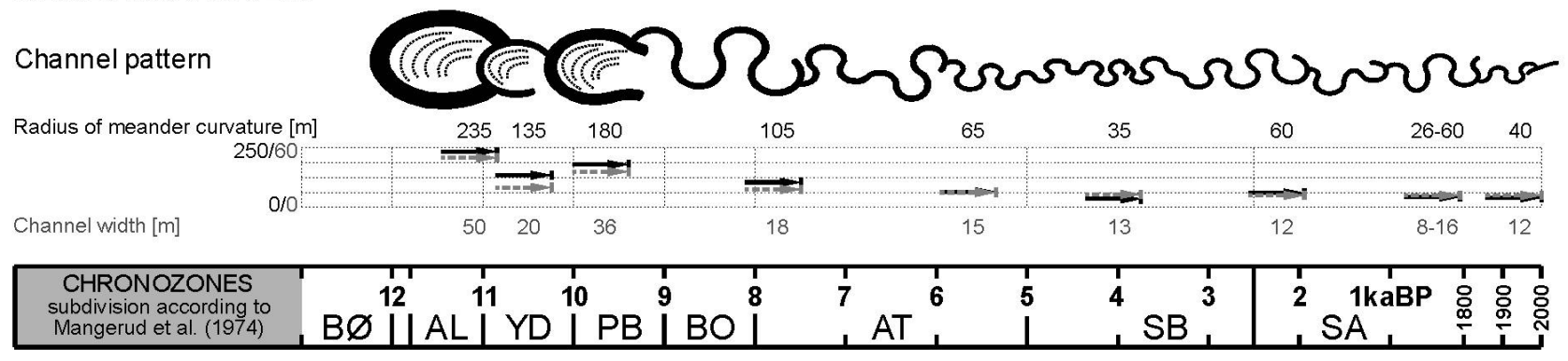

SAN RIVER (Szumański, 1986)

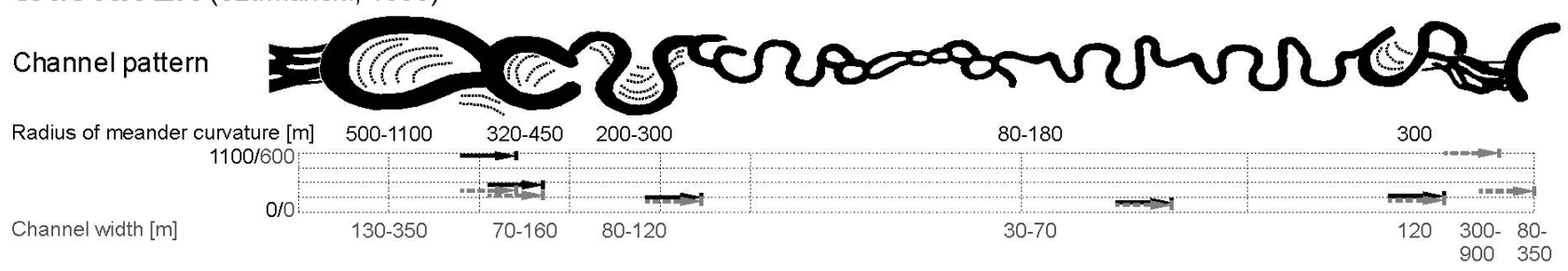

VISTULA RIVER IN THE WESTERN PART OF SANDOMIERZ BASIN (Kalicki, 1991; 2006)
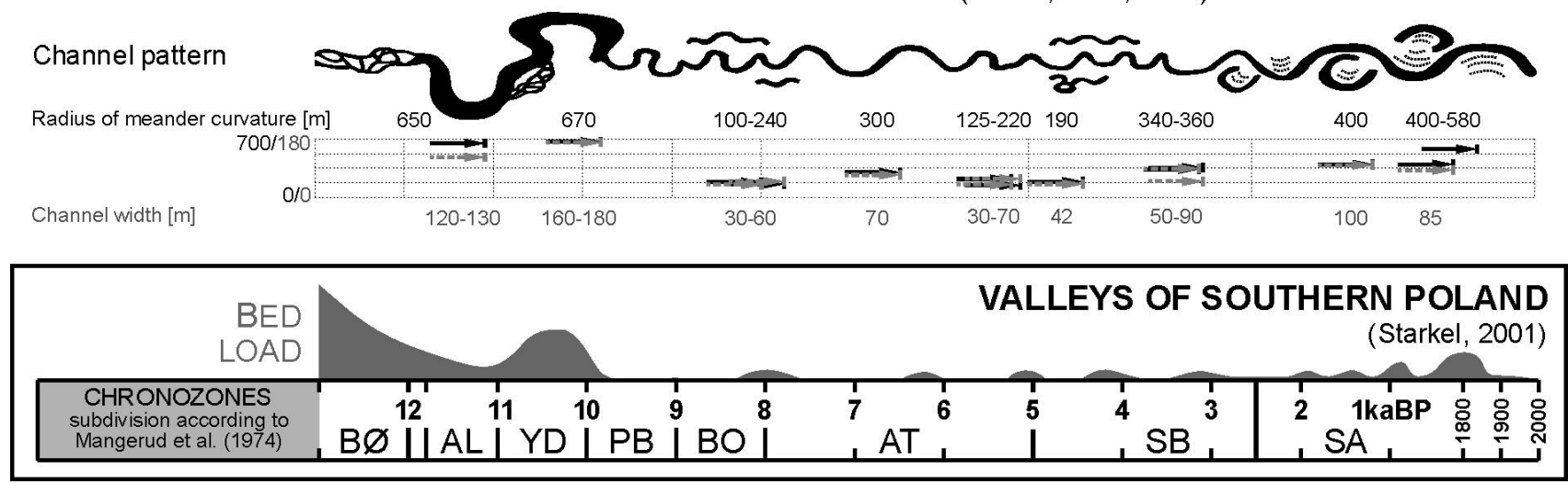

Fig. 4. The river channel changes and relative rate of bed-material load and sedimentation in the Kłodnica valley and other valleys of southern Poland (according to different authors). 
palaeomeanders are common in southern Poland among others in the valleys of the Vistula, Wisłoka and San Rivers (Szumański and Starkel, 1990). According to Szumański (1986), palaeomeander parameters of the San River were successively decreasing since Allerød and in the Pre-Boreal they were lower than at the end of the Late Glacial. However, the Vistula River in some reaches downstream of Cracow started braiding again in response to Younger Dryas conditions (Kalicki, 1991), which proves that there was an essential increase of bed load in that period (Starkel, 2001). Aforementioned differences do not influence the final conclusion that - in valleys of southern Poland - channel-forming flows in the Late Vistulian and, probably, at the beginning of the Holocene could have been a few times higher than the present ones (see Rotnicki, 1991). Bed load was the main type of riverine transport at that time. As a result, thickness of channel deposits of the Kłodnica River from that period is relatively high. For example, point-bar deposits of the palaeomeander at the Sławięcice site have thickness reaching about $2.8 \mathrm{~m}$. The large meanders, forming a wide meander belt, undercut valley sides which led to valley-bottom widening. Until present time, deposits from that age have been preserved in zones adjacent to the valley sides occupying broad areas of the valley floor.

In the Holocene, palaeomeanders size reduction and, in effect, the width limitation of the Kłodnica meander belt occurred. The radius of the palaeomeander at the Sławięcice 2 site, which was cut off earlier than $7480 \pm 60$ ${ }^{14} \mathrm{C}$ yr BP (Ki-11230), is still considerable ( $\left.\mathrm{Rm}=105 \mathrm{~m}\right)$, whilst the palaeomeander at the Rudziniec site shaped before $5350 \pm 70{ }^{14} \mathrm{C}$ yr BP $(\mathrm{Ki}-11885)$ is significantly smaller $(\mathrm{Rm}=65 \mathrm{~m})$. There have been no confirmed evidences of Mid-Atlantic palaeomeanders enlargement in the Kłodnica valley so far. A temporary increase in meander sizes at that period was recorded in the upper Vistula valley among others (Kalicki, 1991). In contrast to the Early and Mid-Holocene, the range of occurrence of Late-Holocene palaeomeanders of the Kłodnica River is limited to a narrow meander belt in the valley axis. In the Kłodnica valley, like in other valleys of southern Poland (Szumański, 1986 and Kalicki, 1991), meanders of small sizes were formed at the turn of the Mid- and Late Holocene. This is exemplified by the palaeomeander at the Las Turbina site $(\mathrm{Rm}=35 \mathrm{~m}, \mathrm{w}=13 \mathrm{~m}, \mathrm{w} / \mathrm{d}=8.1)$ that according to ${ }^{14} \mathrm{C}$ dating could have been an active channel during the Late Sub-Boreal. Similar, usually not much bigger parameters $(\mathrm{Rm}=26-60 \mathrm{~m}, \mathrm{w}=8-16 \mathrm{~m}, \mathrm{w} / \mathrm{d}=5.3-10.7)$ have palaeomeanders dated at the Sub-Atlantic. This contradicts the situation in many valleys of southern Poland, like in the Vistula valley, where geometric parameters of palaeomeanders significantly increased in the Sub-Atlantic (Kalicki, 1991). In the San valley the increase of bed load in the last centuries led initially to the increase of meanders size and later at the turn of the $18^{\text {th }}$ and the $19^{\text {th }}$ centuries led to the transition from a meandering to a braided channel (Szumański, 1986). Aforementioned temporal variability of hydraulic geometry parameters of the Kłodnica palaeomeanders indicates successive decrease of the channel facies accumulation rate throughout the Holocene, with a minimum at the beginning of the Sub-Boreal and in the last two centuries.
Decreasing of $\mathrm{w} / \mathrm{d}$ ratio indicates that the Kłodnica has become the river characterized by more equable hydrological regime and suspended load. In effect, thickness of channel alluvium has decreased. This is exemplified by the Subatlantic palaeomeander at the Folwark Kobylec site whose point-bar has thickness reaching $1.2 \mathrm{~m}$.

\section{Overbank deposits}

Despite high activity of channel processes, overbank deposits accretion in the Late Glacial occurred in the Kłodnica valley on a relatively low scale. The evidence of that is small thickness (like at the Lany Małe site) or even a lack of overbank deposits cover in the preserved from that period parts of the valley bottom. On the other hand, Lateglacial overbank sediments were found at the lowest part of oxbow fills at the Ujazd/Zandrzyny (older than $10850 \pm 310{ }^{14} \mathrm{C}$ yr BP (Gd-10821)) and Plawniowice sites (where accumulation started before $10240 \pm 170{ }^{14} \mathrm{C}$ yr BP (Gd-10812) and was continued into the Holocene). It appears generally that Lateglacial overbank sedimentation in the Kłodnica valley occurred on a smaller scale than in valleys of Carpathian rivers (Starkel, 2001) (Fig. 5). The investigations in the Vistula valley downstream of Cracow enabled to distinguish two phases of intensified overbank deposition corresponding to the Older and Younger Dryas (Kalicki, 1991; 1996).

At the beginning of the Holocene further limitation of overbank facies accretion took place in the Kłodnica valley. This is exemplified by lack of overbank deposits in the oxbow fill at the Sławięcice site, where Pre-Boreal peat directly overlying channel sands. Abandoned channel fills at the Ujazd/Zandrzyny and Las Czajka sites do not contain Holocene overbank deposits. A participation of extra-channel sediments rises, however, in the fills of increasingly younger oxbows. Considered deposits appear especially in the lowest parts of the studied fills. It is conceivable that their accumulation followed processes leading to cut-offs of meander loops. According to radiocarbon dating, a deposition of fine-grained alluvium at the Sławięcice 2 site took place about $7480 \pm 60{ }^{14} \mathrm{C}$ yr BP (Ki-11230). After a period of inactivity, a renewed increase of flood frequency was recorded around $4290 \pm 60$ ${ }^{14} \mathrm{C}$ yr BP (Ki-13092) at that site. Radiocarbon dates from the Rudziniec and Sławięcice/Kolonia sites suggest that an overbank sediment delivery to these oxbows could have taken place in the decline of middle and in the younger (?) parts of the Atlantic Interval. At the Las Turbina site, accumulation of the lower layer of overbank deposits was started not earlier than $3370 \pm 60{ }^{14} \mathrm{C}$ yr BP (Ki-11227). Generally, an accretion of extra-channel alluvium was not too intensive during the analysed part of the Holocene. Nevertheless, numerous sedimentary episodes were recorded in the Kłodnica valley, which can be correlated with flood phases distinguished for rivers of southern Poland (Starkel, 2001). According to research by Kalicki (1991; 1996), the Holocene increase in overbank sediment delivery in the upper Vistula valley took place between: 9800-9300, 8500-8000, 6700-6000, 5500$5000,4500-4000,3500-3000,2700-2600,2200-1800{ }^{14} \mathrm{C}$ yr BP, 5-6 ${ }^{\text {th }}, 10-11^{\text {th }}, 13-14^{\text {th }}$ centuries and in the Little Ice Age. 


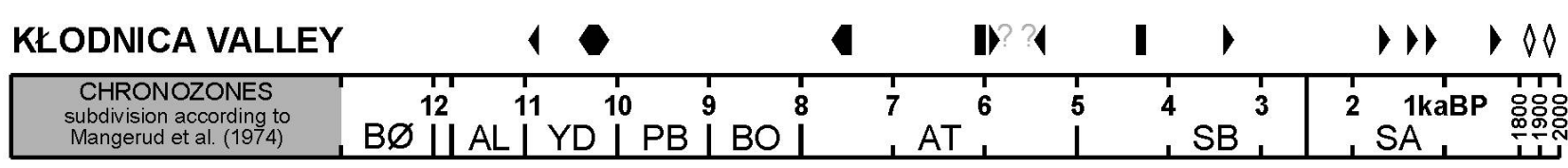

WISŁOKA VALLEY (Alexandrowicz et al., 1981; Starkel, 2001)

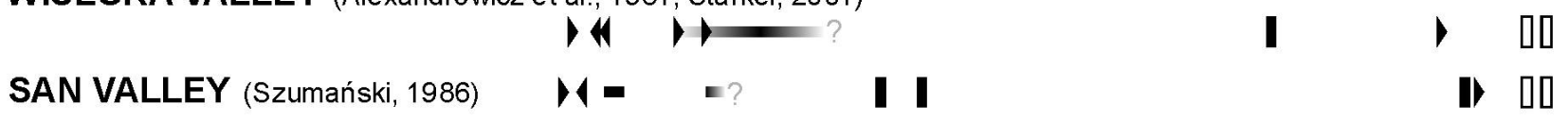

VISTULA VALLEY IN THE WESTERN PART OF SANDOMIERZ BASIN (Kalicki, 1991; 1996)

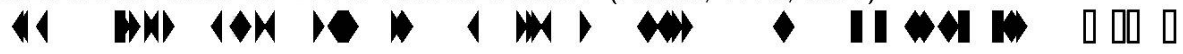

RUDA AND OSOBŁOGA VALLEYS (Klimek, 1999; 2003; Wójcicki, 2006)

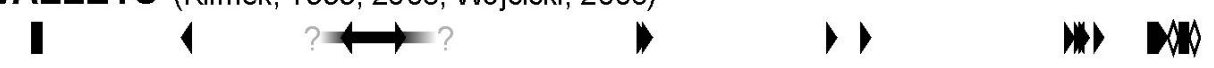

BELNIANKA VALLEY (Ludwikowska-Kędzia, 2000)

(1)

NIDZICA VALLEY (Michno, 2004)
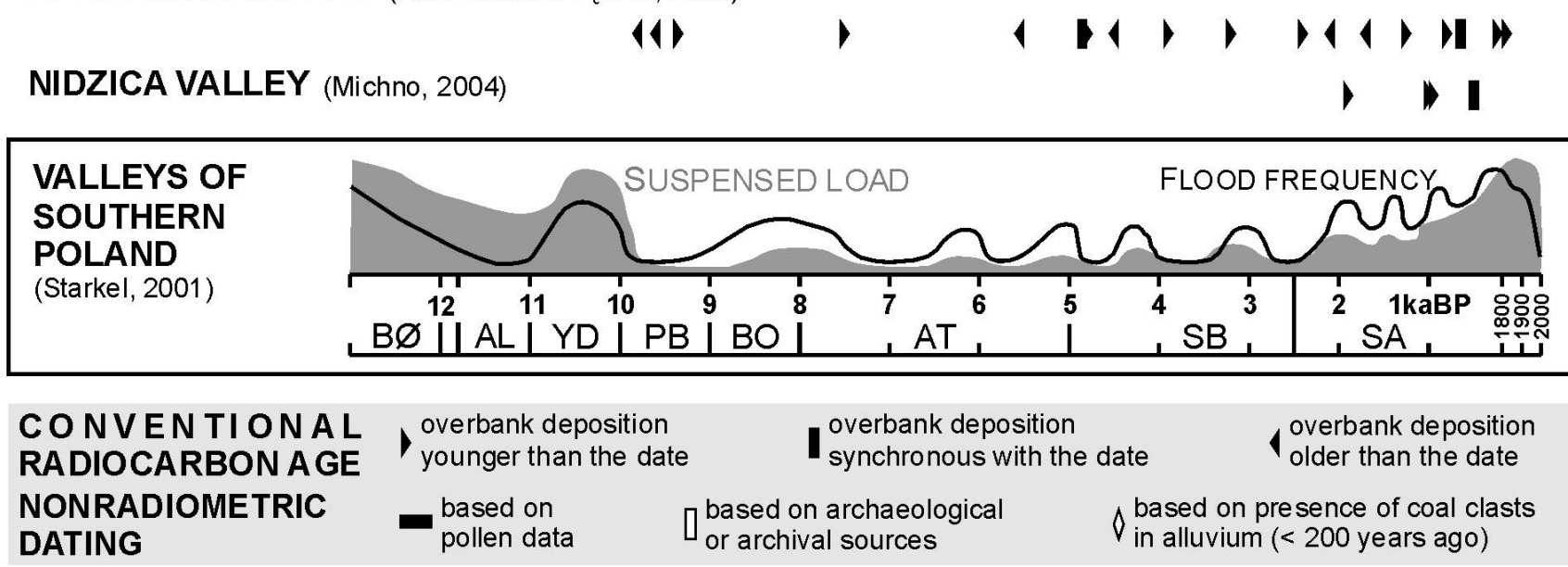

Fig. 5. Chronology of overbank deposits in the Kłodnica valley and corresponding sediments, flood frequency and relative rate of suspensed-material load in other valleys of southern Poland (according to different authors).

The intensive overbank sedimentation was, however, recorded in sequences of deposits from the Sub-Atlantic period. At the Łany Małe site overbank deposits overlie peat, whose top was dated at $1720 \pm 80{ }^{14} \mathrm{C}$ yr BP (Ki7583). In an analogous situation at the Huta Piła core, the date $1215 \pm 70{ }^{14} \mathrm{C}$ yr BP (Ki-7573) was obtained. At the Las Turbina site, as a result of alluvium supply about $520 \pm 60{ }^{14} \mathrm{C}$ yr BP (Ki-11226), a younger phase of biogenic accumulation was stopped. At the Wydzierów and Folwark Kobylec sites, coal clasts were accumulated with overbank deposits. It is an evidence that the intensive overbank sedimentation also occurred throughout the last two centuries in the period of development of coal mining in the upper part of the Kłodnica River catchment. In effect of intensive overbank sedimentation, lasting almost the last 2000 years, alluvia of vertical accretion occupy the entire width of the Kłodnica valley floor between Pławniowice and Ujazd. The thickness of these deposits varies usually from 0.2 to $0.8 \mathrm{~m}$, although locally exceeds $1.5 \mathrm{~m}$. Intensive Late-Holocene overbank sedimentation is common in valleys of southern Poland, both in the upper Vistula (Alexandrowicz et al., 1981; Szumański, 1986; Starkel, 2001 and Michno, 2004) as well as in the upper Odra basins (Klimek, 1999, 2002 and Wójcicki 2006). According to Lajczak (1995), the largest increase of overbank sedimentation rate at the Carpathian Fore- land took place from the beginning of the $16^{\text {th }}$ to the middle of the 20 th centuries.

\section{Tributary fan facies}

In the Kłodnica valley tributary fan deposits form both (1) alluvial fans located at the mouth of perennial streams to the main valley and (2) proluvial fans developed at the mouth of ephemeral streams which drain loess-covered Proboszczowice Plateau. The first category includes extensive fans appearing on the both sides of the valley. It is exemplified by the Chmielnik site. The outcrop was made in a distal part of the fan (see Fig. 3), where fine-grained alluvial fan deposits overlap with floodplain sediments. The date $9620 \pm 120{ }^{14} \mathrm{C}$ yr BP (Ki11889), which was obtained from the top of peat underlying the most distal part of the fan suggests, that processes of intensive fan progradation took place probably in the Vistulian. That interpretation is confirmed by examples taken from the Vistula valley, where extensive alluvial fans of the upper Vistula (Niedziałkowska et al., 1985), Raba, Uszwica and Dunajec Rivers (Gębica, 1995 and Starkel, 2001) progradated rapidly during the cooler periods of the Plenivistulian. Intensive development of alluvial fans was continued throughout the Late Vistulian. Numerous Lateglacial forms were recognized in the Wieprz valley (Kociuba and Brzezińska-Wójcik, 1999). 
According to Gębica (1995), an aggradation of the Raba and Uszwica fans in the Vistula valley escalated probably during the Bølling and between $10800-10400{ }^{14} \mathrm{C}$ yr BP (Fig. 6). In the Holocene, the aggradation of the fan surface at the Chmielnik site occurred slowly. Contrary to coarse-grained inorganic Vistulian deposits, Holocene sediments were deposited in conditions of low flow dynamics with frequent intervals marked by organic lamina development (date $7440 \pm 70{ }^{14} \mathrm{C}$ yr BP (Ki-13085)). More or less at that time, in the Wisłoka and Wisłok drainage basins at the Carpathian Forelands, alluvial fans of minor rivers progradated rapidly (Starkel et al., 1999). In the Wisłoka valley, a 5-meter-thick series of alluvial fan deposits of the Maga stream arose in effect of - at least 95 flood events between $8390 \pm 105$ and $7785 \pm 145{ }^{14} \mathrm{C}$ yr BP (Starkel, 2001). It seems that a sedimentation rate of alluvial fan deposits in the Kłodnica valley was considerably lower. In the Mid- and Late Holocene, vertical accretion of a distal part of the fan at the Chmielnik site amounted to $0.8 \mathrm{~m}$ only.

A history of proluvial fans developed at the mouth of loess gullies was different. By radiocarbon dating, alluvial fans of ephemeral streams in the Kłodnica valley arose in the Sub-Atlantic. At the Ujazd/Zandrzyny site, peat was covered by silty deposits younger than $2240 \pm 100(\mathrm{Ki}-8535), 1090 \pm 90(\mathrm{Ki}-8537), 835 \pm 80$ (Ki8536) and $780 \pm 120{ }^{14} \mathrm{C}$ yr BP (Gd-10810) (Klimek, 2003). It can be evidence of a multi-stage progradation of proluvial fan at that site. At the Gaj site, deposits from a distal part of the fan overlie peat dated at the top at $1010 \pm 70{ }^{14} \mathrm{C}$ yr BP (Ki-11888). Present observations and dendrogeomorphological analyses indicate a continuation of gully erosion processes within the loess plateau (Malik, 2008) as well as proluvial fan forming on the valley floor. In effect, a rapid accretion of tributary fan deposits occurs recently, especially on the right side of the valley bottom between Pławniowice and Ujazd. LateHolocene tributary fans developing in the neighbourhood of human settlements are common in loess areas of southern Poland. The development of proluvial fan at Bronocice in the Nidzica valley occurred in two stages and was stopped probably after the Neolithic settlement fall (Śnieszko and Grygierczyk, 1991 and Śnieszko 1995). The proluvial fan in the Psina valley is chronologically younger; its development took place in the Bronze and Iron Age (Zygmunt, 2004). The maximum progradation of proluvial fans in the Mleczka River drainage basin corresponds with the early Middle Ages (Klimek et al., 2006). The initiation of proluvial fan progradation at Młodzawy in the Nida valley was dated at less than $1050 \pm 80{ }^{14} \mathrm{C}$ yr BP. However, history of the neighbouring alluvial fan of the Mozgawka Stream is probably about 1100 years longer according to radiocarbon dating (Szwarczewski, 2007). Also an increase of alluvial fans aggradation of the Raba and Uszwica Rivers in the Vistula valley was noticed throughout the SubAtlantic (Gębica, 1995).

\section{Slope facies}

Slope deposits play a minor role in valley fills of southern Poland. It is one of the reasons why chronology of slope processes intensification is based on a small number of sites, usually isolated in particular valleys (Fig. 7).

It is difficult to estimate intensity of slope facies supply in the Kłodnica valley in the Late Vistulian. PreHolocene sheetwash deposits occur, among others, on northern hillsides of the valley near Łany Małe. There are

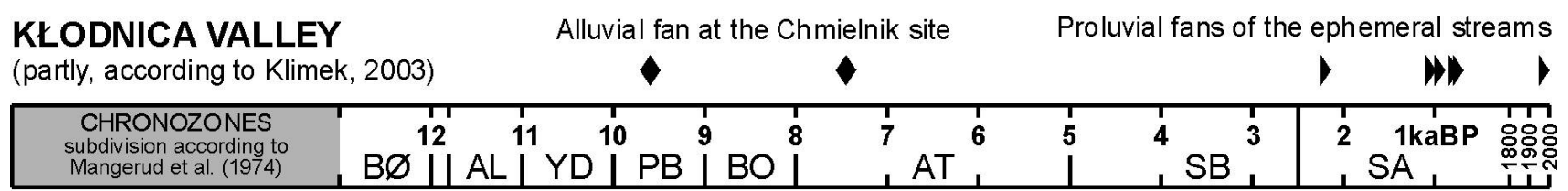

WISŁOKA VALLEY (Niedziałkowska et.al., 1977; Alexandrowicz et.al., 1981; Starkel, 2001)

Alluvial fan of the Maga Stream

NIDZICA VALLEY (Śnieszko and Grygierczyk, 1991; Śnieszko, 1995)

Proluvial fan of the ephemeral stream at Bronocice

VISTULA VALLEY - Alluvial fans of the Raba and Uszwica Rivers (Gębica, 1995)

\section{1}

PSINA VALLEY (Zygmunt, 2004)

Proluvial fan of the ephemeral stream at Borucin

MAIN VALLEY (MLECZKA RIVER BASIN) (Klimek et. al., 2006)

Proluvial fans of the ephemeral streams

NIDA VALLEY (Szwarczewski, 2007)

Alluvial fan of the Mozgawka Stream and proluvial fan of the ephemeral stream at Młodzawy

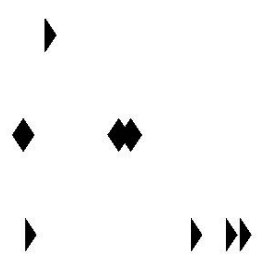

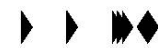

$$
\begin{aligned}
& \text { CONVENTIONAL } \\
& \text { RADIOCARBON AGE }
\end{aligned} \quad \begin{aligned}
& \text { fan aggradation } \\
& \text { younger than the date }
\end{aligned} \quad \begin{aligned}
& \text { fan aggradation } \\
& \text { older than the date }
\end{aligned}
$$

Fig. 6. Chronology of tributary fan deposits in the Kłodnica valley and corresponding sediments in other valleys of southern Poland (according to different authors). 


\section{KŁODNICA VALLEY}

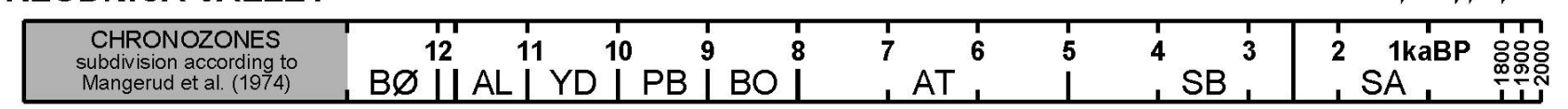

VISTULA VALLEY IN THE WESTERN PART OF SANDOMIERZ BASIN (Godłowska et. al., 1988)

Pleszów site

PSARKA VALLEY (Śnieszko, 1995)

Sieradowice site

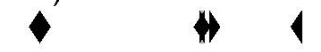

(

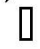

[ $\quad 00$

WIEPRZ VALLEY: Topólcza site (Kociuba and Brzezińska-Wójcik, 1999)

BELNIANKA VALLEY: Napęków site (Ludwikowska-Kędzia, 2000)

PRUDNIK VALLEY: Biała site (Klimek, 2003)

NIDA VALLEY: Sites at the vicinity of Mozgawa (Szwarczewski, 2007)

ODRA VALLEY: Większyce and Ligota sites (Wójcicki, unpublished)

$M$

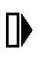

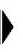

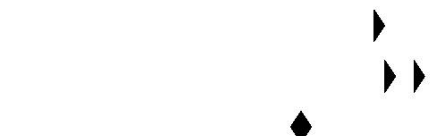

1

\section{CONVENTIONAL RADIOCARBON AGE}

PHASES OF MECHANICAL DENUDATION

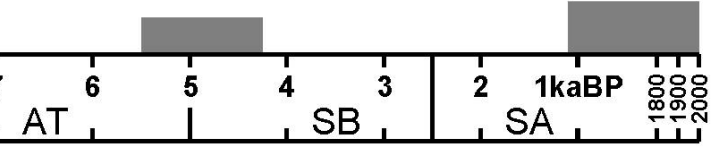

Fig. 7. Chronology of slope deposits in the Kłodnica valley and corresponding sediments in other valleys of southern Poland against the background of phases of mechanical denudation (according to different authors).

sandy/loamy rhythmites characterized by tabular lamination and dips of the layers related to valley-side slope angle. These deposits lacking organic matter should be correlated, however, with the periglacial period of the last glaciation. An additional argument supporting this interpretation is a good state of preservation of erosional edges formed during the Late Vistulian by large meanders of the Kłodnica River. Only some of these edges were remodelled by denudational processes, however, by radiocarbon dating it occurred only in the Late Holocene. The aforementioned circumstances indicate that activity of slope processes in the Kłodnica valley in the Late Vistulian was insignificant. It is not contradictory to results of investigations conducted in loess-covered areas of southern Poland. According to Jersak et al. (1992), in some of those valleys sedimentation change from minerogenic to organic/chemical took place before the Allerød. In some of them only intensification of sheetwash and gully erosion was recorded at the turn of: (1) the Oldest Dryas and Bølling (31\% of the analyzed valleys), (2) the Older Dryas and Allerød (68\%) and (3) the Younger Dryas and Pre-Boreal (62 \%) (Śnieszko, 1995).

With more confidence, we can analyze efficiency of slope processes in the Kłodnica valley in the Holocene. At that time numerous oxbows, located at the foot of valley slopes, were filled with biochemical sediments. Each delivery of slope deposits would have been recorded in the analyzed fills. There is no such record in sequences deriving from the Early and Middle Holocene. It applies both to the oxbows located at the foot of hill slopes of the loess-covered Proboszczowice Plateau (the Ujazd/Zandrzyny site) as well as to the oxbows located at the foot of sandy slopes of the Rachowice Plateau and
Koźle Plain (e.g. the Sławięcice and Sławięcice 2 sites). Also in other valleys of southern Poland there is a lack of such a record prior to the Neolithic Age. One of the oldest is the site at Pleszów in the Vistula valley, located at the foot of a loess terrace that was deforested and used for agriculture by Lengyel Culture people (Godłowska et al., 1988). The initiation of sheetwash processes after $5830 \pm 45{ }^{14} \mathrm{C}$ yr BP stopped peat accumulation in the Vistula oxbow. The oldest records of slope process activity in the vicinity of Mozgawa in the Nida valley were dated at less than $5890 \pm 100$ and $4420 \pm 100{ }^{14} \mathrm{C}$ yr BP (Szwarczewski, 2007). According to Śnieszko (1995) large intensity of mechanical denudation in loess areas occurred during the period of Funnel Beaker Culture settlement in the older Sub-Boreal. Later populations in the Neolithic Age, the Bronze Age and probably the older part of the Iron Age had a minor impact on development of denudation. Another increase in slope process activity, recorded commonly in all the investigated valleys of southern Poland (see Fig. 7), took place in the SubAtlantic. The high sedimentation rate of slope deposits in loess areas was maintained, according to Śnieszko (1995), during the last millennium (especially in the 10$11^{\text {th }}, 14^{\text {th }}$ and $17^{\text {th }}$ centuries). By radiocarbon dating, slope deposits in the Kłodnica valley were also accumulated during the younger part of the Sub-Atlantic. At the Sławięcice site, deposition of sandy slope deposits preceded by appearing of synanthropic plant pollen (Nita and Wójcicki, 2005) was dated at less than $1305 \pm 70{ }^{14} \mathrm{C}$ yr BP (Ki-7566). The tops of peats covered by slope deposits were dated at $720 \pm 60{ }^{14} \mathrm{C}$ yr BP (Ki-11231) at the Las Czajka site, at $540 \pm 60{ }^{14} \mathrm{C}$ yr BP (Ki-11886) at the Bany site, and at $200 \pm 60{ }^{14} \mathrm{C}$ yr BP $(\mathrm{Ki}-11229)$ at the 
Sławięcice 2 site. Appearing of slope deposits in upper parts of sedimentary sequences from the Kłodnica valleyfill is quite common and was also recorded at the Pławniowice and Rudziniec sites.

\section{Biochemical facies}

Biochemical deposits are an important component of the Late-Quaternary valley fill of the Kłodnica River. They commonly appear in oxbow and backswamp fills. The oldest deposits of calcareous mud were dated at the Ujazd/Zandrzyny site at the beginning of the Younger Dryas (date $10850 \pm 310{ }^{14} \mathrm{C}$ yr BP (Gd-10821)). However, other radiocarbon dates obtained from peat and carbonate deposits indicate that intensive accretion of biochemical sediments occurred in the Holocene (Fig. 8). The complete view of productivity of peatlands in the Kłodnica valley was obtained thanks to the palaeobotanically studied cores at Łany Małe and Sławięcice (Nita and Wójcicki, 2005). The Łany Małe site represents deposits of mire that occupying flood-basin depression. Despite the date $6240 \pm 70{ }^{14} \mathrm{C}$ yr BP (Ki-7571), peat accumulation at that site started probably in the Early PreBoreal according to pollen data. The Sławięcice site, where peat initiation took place in the Pre-Boreal (date $9400 \pm 90{ }^{14} \mathrm{C}$ yr BP (Ki-7157)), represents fen localized in the abandoned river channel. Holocene history of peat development recorded in these two localities is similar. Like in the Vistula (Mamakowa, 1970 and Kalicki and Zernickaya, 1995) and Belnianka valleys (Szczepanek, 1982 and Ludwikowska-Kędzia, 2000), the highest peat growth rate occurred in the Early Holocene. In the MidHolocene biogenic accumulation was interrupted, which was recorded in the form of decayed peat horizons. Stopping peat growth occurred at that time also in numerous valleys of Carpathian rivers. Intense supply of overbank sediments was responsible for it in the Vistula valley (Mamakowa, 1970 and Kalicki and Zernickaya, 1995). The same reason determined stopping peat accumulation at the Roztoki site in the Jasiołka valley, while beyond the main valley (at the Tarnowiec site) peat accumulation was continued at that time (Wójcik, 1987 and Harmata, 1987). Radiocarbon dates show that biochemical facies accretion in the Mid-Holocene could also be continued at some sites in the Kłodnica valley. Such conditions, favourable to biochemical accumulation, remained certainly at the Ujazd/Zandrzyny site among others. At that site sediments with the largest content of $\mathrm{CaCO}_{3}$ (61.1$79.0 \%$ ) were accumulated about $4220 \pm 80{ }^{14} \mathrm{C} \mathrm{yr} \mathrm{BP}(\mathrm{Ki}-$ 7579). It may point at large intensity of carbonate leaching and precipitation at the decline of the Early SubBoreal. According to pollen data, a restart of peat productivity in the Łany Małe fen could take place in the older

KŁODNICA VALLEY (Nita and Wójcicki, 2005)

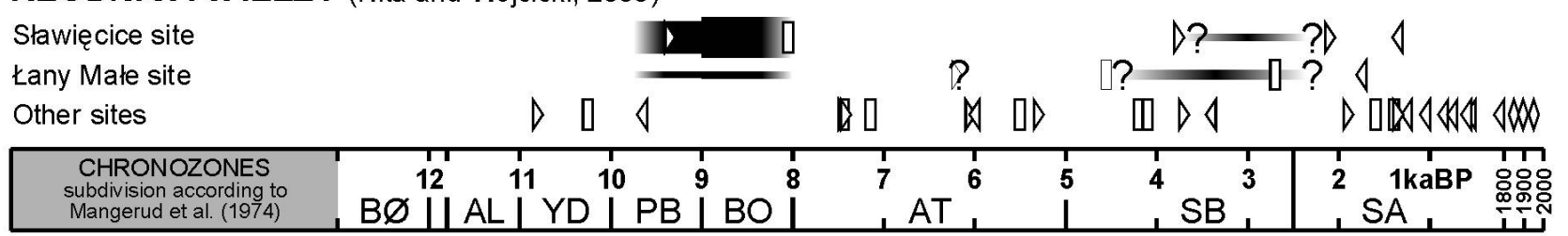

VISTULA VALLEY IN THE WESTERN PART OF THE SANDOMIERZ BASIN

Rondo Mogilskie site (Mamakowa, 1970)

Nowa Huta site (Kalicki and Zernickaya, 1995)
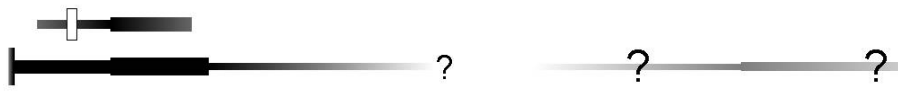

BELNIANKA VALLEY

Stopiec site (Szczepanek, 1982)

Napęków site (Ludwikowska-Kędzia, 2000)

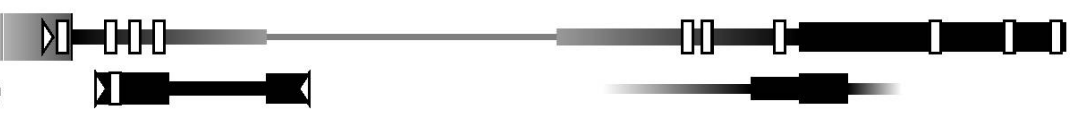

JASIOKKA VALLEY (Harmata, 1987; 1995)

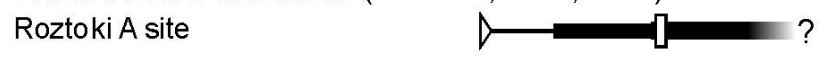

WIEPRZ VALLEY (Bałaga, 1998)

Krasnobród site
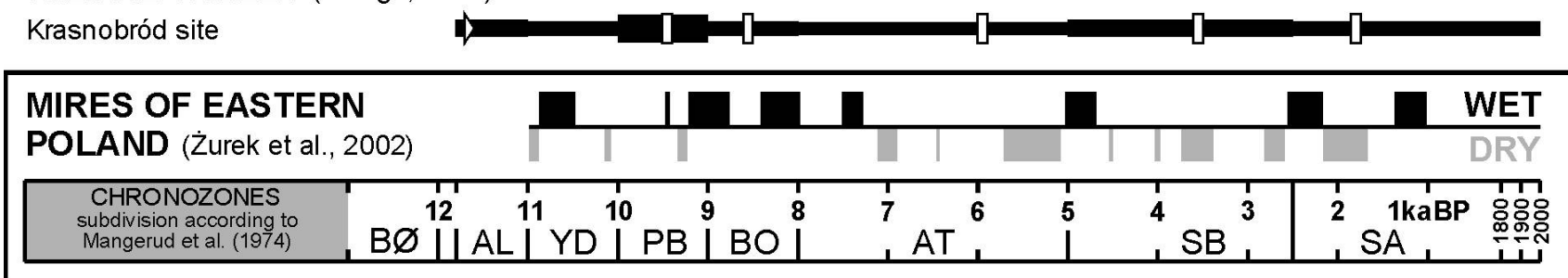

\section{CONVENTIONAL RADIOCARBON AGE dating of initiation of
organic matter accretion dating of organic $\checkmark$ organic matter accretion matter accretion organic matter accretion \\ NONRADIOMETRIC DATING $\backslash$ based on presence of coal clasts in alluvium underlying peat layers $(<200$ years ago) POLLEN CHRONOLOGY

Fig. 8. Chronology of biochemical deposits in the Kłodnica valley and corresponding sediments in other valleys of southern Poland against the background of palaeohydrological changes in mires of eastern Poland (according to different authors). 
and in the Sławięcice fen in the middle part of the SubBoreal period (Nita and Wójcicki, 2005). Perhaps peat accumulation started again in that period also at Nowa Huta in the Vistula valley (Kalicki and Zernickaya, 1995) and at Napęków in the Belnianka valley (LudwikowskaKędzia, 2000). A transition from negative to positive side of the peat mass balance was probably a long-lasting process because organic sediments accumulated above the hiatuses at the Lany Małe and Sławięcice sites are characterized initially by a high degree of decomposition. It may be one of the reasons of discrepancy between results of the pollen analysis and radiometric dating. At the Sławięcice site, the AMS date $2130 \pm 30{ }^{14} \mathrm{C}$ yr BP (Poz-23206) was obtained as a result of dating of Rubus idaeus and Sambucus nigra seeds from the depth of 0.77 $0.79 \mathrm{~m}$. A negative influence on the age measurement at the Lany Małe site $\left(2720 \pm 70{ }^{14} \mathrm{C}\right.$ yr BP (Ki-7569)) could have intrusive remains of alder roots present in the dating sample.

The accumulation of biochemical deposits in the Kłodnica valley was limited in the Late Holocene by supply of overbank, tributary fan or slope sediments. At the Lany Małe site it took place later than $1720 \pm 80{ }^{14} \mathrm{C}$ yr BP (Ki-7583) whilst at the Sławięcice site about $1305 \pm 70$ ${ }^{14} \mathrm{C}$ yr BP (Ki-7566). Interrupting biogenic accumulation at the Gaj site took place not earlier than about $1010 \pm 70$ ${ }^{14} \mathrm{C}$ yr BP (Ki-11888), at the Las Czajka site about $720 \pm 60{ }^{14} \mathrm{C}$ yr BP (Ki-11231), at the Las Turbina site about $520 \pm 60{ }^{14} \mathrm{C}$ yr BP (Ki-11226), at the Bany site about $540 \pm 60{ }^{14} \mathrm{C}$ yr BP $(\mathrm{Ki}-11886)$ and at the Sławięcice 2 site about $200 \pm 60{ }^{14} \mathrm{C}$ yr BP (Ki-11229). Currently, there are conditions for peat accumulation again at the Wydzierów site among others.

History of biochemical deposits accretion in the Kłodnica valley is similar to observations from the Belnianka valley (Ludwikowska-Kędzia, 2000) where two/three phases of peat growth were recorded: (1) from the beginning of the Holocene to the Mid-Atlantic, (2) since the turn of the Atlantic and Sub-Boreal locally till present times, (3) since about 2000 yr BP. It should be emphasized, however, that biogenic sedimentation in numerous sites of southern Poland occurred probably continuously throughout the Holocene, alternatively it only slowed down in the Mid-Holocene. The examples of that are the Krasnobród and Tarnawatka sites in the upper Wieprz valley (Bałaga, 1998). Thus, variability in peat accumulation rates was determined probably by both regional (climatic) as well as local (topographic and lithological) factors.

Environmental variables and changes in depositional style through time in the Kłodnica valley and other valleys of southern Poland

Study results from the Kłodnica valley as well as from other valleys of southern Poland indicate changes in accumulation intensity of particular facies of valley-fill deposits at the decline of the Vistulian and throughout the Holocene (Fig. 9).

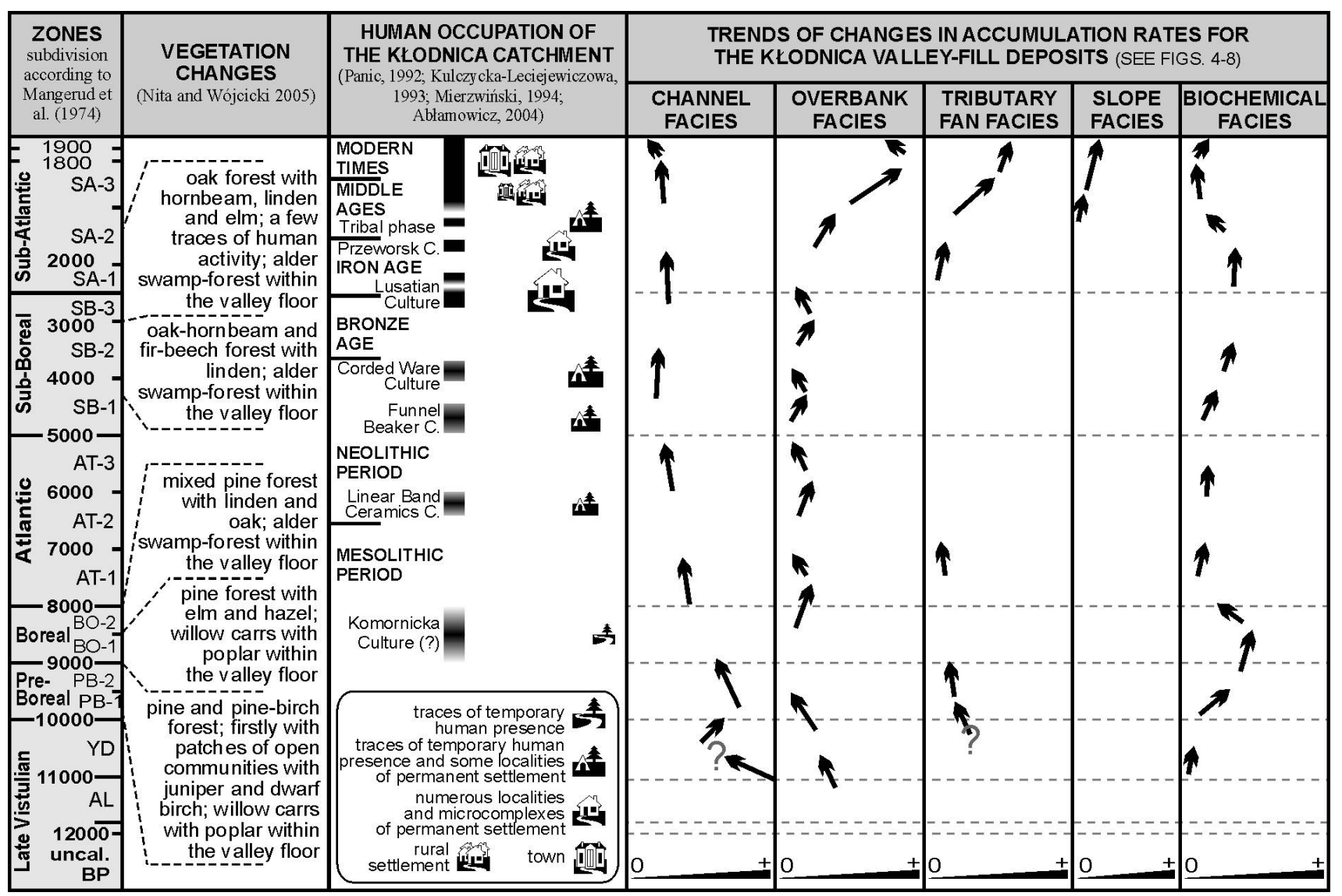

Fig. 9. The main tendencies of changes in sedimentary style in the Kłodnica valley against the background of environmental conditions. 


\section{The Late Vistulian - the Middle Pre-Boreal}

The postglacial evolution of river valleys in southern Poland was initiated in Bølling/Allerød. Its beginning is marked by incision of Pleniglacial valley bottoms and changes in the channel pattern (e.g. Alexandrowicz et al., 1981; Szumański, 1986; Kalicki, 1991 and Starkel, 2001). A transition of the Kłodnica river channel from braided to meandering took place probably at the same time (earlier than $10850 \pm 310{ }^{14} \mathrm{C}$ yr BP $(\mathrm{Gd}-10821)$ ). The Lateglacial stage of the valley development began simultaneously. The mentioned period was characterized by: (1) intensive sedimentation of fluvial deposits, especially of channel facies, (2) little importance of biogenic accumulation. Defining the role of slope processes in that stage is difficult to estimate at present state of knowledge. On the other hand, through the analogy to loess areas (Śnieszko, 1995), we can assume significant progradation of tributary fan deposits in the valley bottom. In comparison to other valleys of southern Poland, fluvial processes in the Kłodnica valley were generally limited to the channel zone. Sedimentation of fine-grained alluvium within the floodplain occurred on a small scale.

It is accepted that high activity of Lateglacial fluvial processes in central and north-western Europe took place in the conditions of flashy hydrological regime (e.g. Rose et al., 1980; Kozarski, 1983 and Bohncke and Vandenberghe, 1991). Bankfull as well as average annual discharges were probably significantly higher than at present. According to estimate released by Rotnicki (1991) for the middle Prosna River, bankfull discharge in the Younger Dryas was about five times higher than at present as a result of a major runoff participation in water balance. It was influenced by cool climate with the July average temperature about $10^{\circ} \mathrm{C}$ during the stadials, though the July average temperature probably rose to about $15^{\circ} \mathrm{C}$ in the Bølling and Allerød interstadials (Kozarski and Nowaczyk, 1999). As a result, a process of replacing low-shrub tundra by open forest dominated by birch (Betula) with European aspen (Populus tremula) and species of willow (Salix) started on the territory of Poland in the Bølling (Ralska-Jasiewiczowa, 1999). According to Kozarski (1983), that was the main reason of river metamorphosis. During the Allerød, open forest occurred - first dominated by birch (Betula), and later dominated by pine (Pinus) with larch (Larix) and spruce (Picea) in uplands of southern Poland. The areas occupied by forest decreased when the climate became colder in the Younger Dryas. Groups of trees including pine (Pinus), birch (Betula) and larch (Larix) formed a landscape of a park with grassy areas or juniper (Juniperus) and ephedra shrubs (Ralska-Jasiewiczowa, 1999). Open grass communities with Artemisia and Chenopodiaceae preserved locally in the Kłodnica catchment till the Early Pre-Boreal (Nita and Wójcicki, 2005). Probably it favoured preserving large meanders at the beginning of the Holocene. Despite vegetation succession characterized above, the protective plant cover in the Late Vistulian was not dense and continuous enough to protect the surface from erosion. High susceptibility of river banks to erosion was favoured by a structure of the valley fill inherited from a period of a braided river development. Through the Late Vistulian, sandy easily washed out deposits were reworked during rising flood waters (Rotnicki and Młynarczyk, 1989). As a result, flows had unusually exceeded bankfull stage and sedimentation of fine-grained alluvia in a distal part of floodplain rarely occurred.

Biochemical accumulation rate was low in the Late Vistulian probably in response to unfavourable climatic and trophic conditions. In water basins and wetlands of southern Poland mainly chalky sediments or gyttja were deposited at that time (e.g. Harmata, 1987 and Bałaga, 1998).

\section{The Middle Pre-Boreal - the Late Boreal}

In the Kłodnica valley and in most valleys of southern Poland this period is characterized by (1) gradual limitation of fluvial deposition, (2) a significant growth of biochemical accumulation and (3) a lack of mechanical denudation on slopes (see Śnieszko, 1995). According to Starkel (2003), the change of sedimentary style in valleys of southern Poland occurred at the Younger Dryas/PreBoreal boundary. In the light of results obtained in the Kłodnica valley, it could take place in the middle part of Pre-Boreal period.

The limitation of fluvial processes activity was connected with climate warming at the beginning of the Holocene. Vegetation changes could not keep up with quick climate warming (Ralska-Jasiewiczowa, 1999). In the older part of the Pre-Boreal pine forest with admixture of birch trees (Betula alba type) existed in the Kłodnica river drainage basin (Nita and Wójcicki, 2005). But, as mentioned above, locally open grassy areas with $\mathrm{Ar}$ temisia and Chenopodiaceae still preserved. Juniper and dwarf birch (Betula nana) occasionally appeared. In the younger part of the Pre-Boreal pollen of the latter is no longer noted. The willow shrubs with elm (Ulmus) and poplar (Populus) grow in the valley bottom at that time. In the Boreal, European filbert (Corylus avellana), oak (Quercus) and small-leaf linden (Tilia cordata) appeared in the forests surrounding the valley. Vegetation pollen appearance, considered to be climatic indicators, suggests that on the territory of Poland temperatures were higher than at present from the middle of the Pre-Boreal at least (Ralska-Jasiewiczowa, 1999). The Early-Holocene warming and vegetation succession lead certainly to the changes of hydrological regime manifesting in gradual limitation and compensation of the river discharges. According to Rotnicki (1991), the bankfull discharge of the middle Prosna River in the Boreal was almost 3-times lower than in the Younger Dryas. In these conditions a relative rate of fluvial deposits accumulation significantly decreased and the width of meander belt was reduced. Vegetation cover started to protect efficiently the soil from erosion. In exchange, processes of peat accumulation and soil formation were initiated on a large scale in the Early Holocene. In many valleys of southern Poland, the highest rate of peat accumulation took place in the Pre-Boreal and Boreal (see Mamakowa, 1970; Szczepanek, 1982; Kalicki and Zernickaya, 1995 and Ludwikowska-Kędzia, 2000). In that period, quickly improving thermal conditions were strengthened by favourable humidity conditions that occurred in the first stage of oxbow and flood-basin terrestrialisation. 


\section{The Late Boreal - the Sub-Boreal}

This period is defined by: (1) relatively low deposition of minerogenic sediments but with periodic increase of valley alluviation, (2) decrease of accumulation rate or even biogenic accumulation break in numerous valleys of southern Poland. Anthropogenically conditioned activization of the slope processes occurred on a small scale and locally only. The beginning of considered period can be linked with an essential increase in accumulation of tributary fan and overbank deposits, which took place in the upper Vistula drainage basin between 8.4-7.7 ka yr BP (Alexandrowicz et al., 1981 and Starkel et al., 1999). In the Kłodnica valley, biogenic accumulation was interrupted in some sites simultaneously. It seems that in valleys of southern Poland sedimentation rates both fluvial and biochemical deposits were higher in the older part of distinguished period. But in the upper Odra basin, we have had no evidence documenting the shift of sedimentary style from the Late Boreal to the Sub-Boreal, thus that period was treated as one stage.

Mid-Holocene sedimentation in valley bottoms developed with a passive role of Mesolithic man first. At that time climax mixed forests with domination of elm ( $U l-$ mus) and European filbert (Corylus avellana) widespread in southern Poland and European alder (Alnus glutinosa) assemblages appeared on wetlands within valley floors (Ralska-Jasiewiczowa, 1999). In such conditions, a course of sedimentation processes were probably connected with hydrological changes determined by wetter or drier climate. Magny (2004), distinguished two episodes of higher lake-level events in the older and middle part of Atlantic Period, between ca. 8300-8050 cal. ${ }^{14} \mathrm{C}$ yr BP (c. $7450-7250{ }^{14} \mathrm{C}$ yr BP) and $7550-7250$ cal. ${ }^{14} \mathrm{C}$ yr BP (c. $6650-6250{ }^{14} \mathrm{C}$ yr BP). It seems that the latter has got a sedimentary record in the fluvial environment on the territory of Poland. The increase of palaeomeander sizes in the Middle Atlantic is noted among others in the upper Vistula (Kalicki, 1991) and in the Prosna valleys (Rotnicki, 1991). What is more, Mid-Atlantic flooding episodes are clearly evident in the valleys of Polish rivers (Starkel, 2001 and Starkel et al., 2006). In the Kłodnica valley, events of increased fluvial activity were recorded at about $7480 \pm 60{ }^{14} \mathrm{C}$ yr BP $(\mathrm{Ki}-11230)$ and at the turn of the Middle and Late Atlantic. Mid-Atlantic enlargement of palaeomeanders was transitory and their sizes decreased again at the decline of the Atlantic Period. According to Rotnicki (1991), bankfull discharges for the middle Prosna River at the beginning of Sub-Boreal achieved lower values than at present. Also, channelforming discharge of the Kłodnica River decreased in the Early Sub-Boreal reaching Holocene minimum. Meander belt was very narrow while channel sinuosity very high, showing the regularity of discharge in annual cycle. Synchronously, processes of peat decay probably still occurred in the Łany Małe and Sławięcice sites. The break of biogenic accumulation during the Atlantic Period was recorded not only in southern Poland but in some sites from valleys of the Czech Republic as well. For example, Rybníček and Rybníčkova (1987) described MidHolocene stratigragraphic hiatuses from the Budějovická pánev Basin and the River Dyje valley. It's not out of the question that the peat decay recorded in some central-
European sites depended on climate humidity reduction at the turn of the Atlantic and Sub-Boreal (see Magny, 2004). The authors, however, often point out non-climatic controls of reduction of peat accretion or stopping biogenic accumulation in the Middle Holocene. These could have been: (1) intensive increase of alluvia sedimentation breaking biogenic accumulation on the floodplain (Mamakowa, 1970; Harmata, 1987 and Kalicki and Zernickaya, 1995), (2) lowering of the ground water table in effect of fluvial incision (Ludwikowska-Kędzia, 2000), or (3) intensive peat decomposition during some successional stages of mire development (Rybníček and Rybníčkova, 1987).

In the Mid-Atlantic Period, a few settlements of Linear Band Ceramics Culture appeared in the Kłodnica drainage basin (Kulczycka-Leciejewiczowa, 1993). Some settlements of Funnel Beaker Culture, known mainly from northern loess part of the Kłodnica drainage basin, originate from the Atlantic/Sub-Boreal transition (Kulczycka-Leciejewiczowa, 1993). Scattered artefacts prove that people of Funnel Beaker Culture penetrated also the studied part of the Kłodnica valley (Abłamowicz, 2004). Nevertheless, the presence of the Neolithic man did not affect a change of depositional style in the Kłodnica valley. According to Śnieszko (1995), the disturbance of homeostasis in the Neolithic Period occurred on a local scale and affected only the nearest neighbourhood of a settled area.

\section{The Sub-Boreal - the Middle Sub-Atlantic}

This period is distinguished by a renewal of peat accretion or an increase in biochemical accumulation rate. Additionally, this stage is characterized by slope stability and periodic increase in alluviation, generally taking place in the conditions of low channel-forming flows and little deposition of alluvium. In the Kłodnica valley, dating of the beginning of that period is ambiguous and requires further works. Accepting of the results of pollen analysis from the Lany Małe site (Nita and Wójcicki, 2005), it seems that conditions favourable of peat productivity could appear already during the Early Sub-Boreal. Similar results were obtained in some other valleys of rivers draining central-European highlands and piedmont basins (e.g. Szczepanek, 1982; Rybníček and Rybníčkova, 1987 and Ludwikowska-Kędzia, 2000).

The sedimentary processes in the Kłodnica valley took place still in the conditions of forests domination, however, significantly transformed in comparison with Mid-Holocene assemblages. It seems that forests dominated by oak and hornbeam (Carpinus) with a large admixture of small-leaf linden widespread on the highlands adjacent to the valley in the middle part of the Sub-Boreal (Nita and Wójcicki, 2005). In the river valley there were assemblages dominated by European alder with an admixture of European ash (Fraxinus excelsior) and elm. A few cereal pollen grains and other indicators of human activity appeared in pollen diagrams from that period. Low NAP values indicate, however, insignificant deforestation of the studied area. At the turn of the Neolithic Age and the Bronze Age people of the Corded Ware Culture appeared within the lower part of the Kłodnica drainage basin (Abłamowicz, 2004). However, a basis of 
their economy was shepherding, which to a little extent influenced a transformation of natural environment only (Kulczycka-Leciejewiczowa, 1993). Intensive and constant settlement appeared with the people of the Lusatian Culture between $2740-2170{ }^{14} \mathrm{C}$ yr BP at the turn of the Bronze Age and the Iron Age (Abłamowicz, 2004). The microcomplex of settlement functioned at that time on the Kłodnica valley sides at Łany Małe. The economy of the people of the Lusatian Culture was based on agriculture and farming, which certainly led to significant forest clearance in the studied part of the catchment. Despite that, soil erosion was not intensive at that time and stressed only by silting up of peat at the Lany Małe site. At the Ujazd/Zandrzyny site local gully erosion was activated (Klimek 2003), however, the ravines development on a large scale took place only from the Middle Ages.

Thus, the development of sedimentary processes from the Early Sub-Boreal to the Middle Sub-Atlantic was determined by climate factors. According to Magny et al. (2006), a series of three episodes of successively higher lake level forced by varying solar activity took place about 5600-5300 cal BP (c. $4900-4550{ }^{14} \mathrm{C}$ yr BP) in central Europe. The renewal of peat accretion recorded in the valleys of southern Poland could be related to SubBoreal climate moistening as well (Ralska-Jasiewiczowa and Starkel, 1988). Synchronously, an increase in water and sediment load took place on the territory of Poland. According to Rotnicki (1991), the bankfull discharge of the Prosna River increased transitionally at the end of the Early Sub-Boreal and was about 2-times higher than at present. More or less at that time an episode of flood deposits delivery was recorded at the Sławięcice 2 site in the Kłodnica valley. The growth of overbank sedimentation between $4500-4000{ }^{14} \mathrm{C}$ yr BP is also known from the Vistula valley (Kalicki, 1991). However, the Kłodnica valley slopes remained stable and the soils develop as well as chemical denudation was predominant in the catchment. The repeated decline of channel-forming flows in the Prosna valley took place at the end of the Sub-Boreal reaching the Holocene minimum of about 2times lower than at present (Rotnicki, 1991). In the Kłodnica valley that kind of changes of palaeomeander sizes has not been recognized. What is more, a little growth of radius of meander curvature took place at the turn of the Sub-Boreal and Sub-Atlantic. Analogous situation, indicating an increase of channel-forming flows and bed load transport, was recorded in the San (Szumański, 1986) and Vistula (Kalicki, 1991) valleys. These changes were preceded by intensified flood sedimentation at the Las Turbina site in the Kłodnica valley younger than $3370 \pm 60$ ${ }^{14} \mathrm{C}$ yr BP (Ki-11227).

\section{The Middle Sub-Atlantic till now}

In valleys of southern Poland, the period of last about 2 ka years is characterized by: (1) a rapid increase in fluvial sedimentation, especially overbank and tributary fan facies, with simultaneous discharge and bed load increase in river channels, (2) common initiation of slope deposition, (3) a limitation of biochemical accumulation in response to mineralogenic sediment supply.

Although fluvial system responses to hydrological changes will have been promoted by anthropogenic dis- turbances of catchment vegetation cover, the timing of Late-Holocene incision and alluviation episodes are interpreted as reflecting enhanced flood frequencies and/or magnitudes associated with Late-Holocene climatic shifts (Anderson et al., 2004; Smith et al., 2005 and Macklin et al., 2006). Similar factors certainly influenced sedimentation processes in the Kłodnica catchment during the last ca. $2 \mathrm{ka}$. That was proceeded by vegetation cover changes recorded in pollen diagrams, namely appearing of human economy indicators showing both cereal cultivation (e.g. Secale cereale, Triticum type) and shepherding (e.g. Plantago lanceolata) (Nita and Wójcicki, 2005). Nevertheless, in the sediments from the turn of the Sub-Boreal and Sub-Atlantic, and perhaps also from the older part of the Sub-Atlantic, a participation of NAP was still low. In the Kłodnica valley there were forest assemblages with alder predominant. Beyond the valley there were forests with domination of oak, and later with hornbeam and lime. As aforementioned, the first stage of agriculture connected with the Lusatian Culture settlement did not lead to a significant mechanical denudation increase. Probably, the climatic conditions are responsible for that because the period $2750-2150$ cal BP (c. $2850-2150{ }^{14} \mathrm{C}$ $\mathrm{yr} \mathrm{BP})$ is characterized by significantly fewer ${ }^{14} \mathrm{C}$ dated flood units in Poland (Starkel et al., 2006 and Macklin et al., 2006). It appears that soil erosion on a larger scale started in the Roman Period. It was related to the Przeworsk Culture settlement whose village existed near the Łany Małe site in $3^{\text {rd }}-4^{\text {th }}$ centuries AD (Abłamowicz, 2004). A maximum of slope process development, overbank sedimentation and alluvial fan progradation occurred in the Kłodnica valley probably in the Middle Ages and modern times. Also, an activity of channel processes was high in the last dozen centuries. Parameters of the hydraulic geometry of river channels increased significantly in relation to palaeomeander sizes at the end of the Sub-Boreal (Szumański, 1986; Rotnicki, 1991 and Kalicki, 1991). A regime of numerous rivers in southern Poland became more flashy, which is indicated by a change of river channel pattern from meandering to braided. In case of the San River that shifts took place at the turn of the $18^{\text {th }}$ and $19^{\text {th }}$ century (Szumański, 1986). Nevertheless in the last few decades, in the upper Vistula basin, an insignificant decrease of overbank sedimentation rate can be observed which is caused by more careful use of land and construction of dams in Carpathian valleys (Lajczak, 1995). Also, specificity of the Kłodnica valley is that in the last two centuries activity of channel processes has seemed to decrease. These tendencies, however, are strictly related to an exploitation of the Gliwice Canal supplied with the Kłodnica waters. Additionally, anthropogenic discharge equalization (Absalon et al., 1996) and the incision of the regulated Kłodnica channel have enabled a renewed peat growth on the floodplain in the last time.

\section{CONCLUSIONS}

The research on fill of a meandering river in the Kłodnica valley indicates periods characterized by changeable intensity of particular facies sedimentation. The largest intensity of channel deposits accumulation 
occurred from the Late Vistulian to the Early Pre-Boreal. Progressive decrease of channel facies accumulation rate took place throughout the Holocene with transitory and insignificant increase at the Sub-Boreal/Sub-Atlantic transition. Overbank and tributary fan sedimentation rates reached relatively high value in the Late Vistulian, but the maximum in the Middle and Late Sub-Atlantic. In the older parts of the Holocene overbank deposition were rather low, but with periodic increases about $7.5 \mathrm{ka}$ years BP, $6.1 \mathrm{ka}$ years BP, $4.3 \mathrm{ka}$ years BP, less than $3.4 \mathrm{ka}$ years BP and perhaps in the Younger Atlantic. A largescale slope deposition was initiated in the Middle Ages. The largest accumulation rate of biochemical facies occurred in the Early Holocene and the older part of the Late Holocene.

Studies showed a lot of common features of the valley development in southern Poland. The changes of sedimentation style in valley bottoms resulted from general energy changes and matter flow within fluvial system. They had allocyclic character and were controlled by environmental variables describing fluvial system. The course of sedimentary processes was first controlled by natural factors: hydrological regime and erosion intensity conditioned by climate and vegetation changes. Human impact in the Kłodnica basin became more significant from the Roman Period and occurred on a large scale from the early Middle Ages. Older settlement phases, including intense settlement from the Hallstatt Period, were not clearly recorded in the Kłodnica valley fill.

\section{ACKNOWLEDGEMENTS}

The National Science Foundation under the 'Track' program and the Silesian University provided financial support for this research. Special thanks go to Prof. Kazimierz Klimek for his support and advice, Dr Małgorzata Nita for cooperation and permission to use the results of her palaeobotanical analyses and Dr Dominik Ablamowicz for sharing his knowledge of the prehistoric settlement of the Upper Silesia. I am grateful to my wife Monika for her help with the translation of the text.

\section{REFERENCES}

Abłamowicz D, 2004. Człowiek i środowisko przyrodnicze w dorzeczu dolnej Kłodnicy w świetle badań archeologicznych i interdyscyplinarnych (Man and natural environment in the lower Kłodnica basin in the light of archaeological and interdisciplinary research). In: Abłamowicz D and Śnieszko Z, eds., Zmiany środowiska geograficznego $w$ dobie gospodarki rolno-hodowlanej (Geographical environment changes in the period of farming and breeding economy). Katowice: 271-292 (in Polish).

Absalon D, Czaja S, Jankowski AT, Kaňok J and Leśniok M, 1996. Tendencje zmian obiegu wody (Tendencies of water circulation changes). In: Jankowski AT, ed., Tendencje zmian obiegu wody $w$ zlewni górnej Odry (Tendencies of changes in water cycle in the Upper Oder catchment). Sosnowiec, Silesian University Press: 59125 (in Polish).

Aguzzi M, Amorosi A, Colalongo ML, Ricci Lucchi M, Rossi V, Sarti $\mathrm{G}$ and Vaiani SC, 2007. Late Quaternary climatic evolution of the Arno coastal plain (Western Tuscany, Italy) from subsurface data. Sedimentary Geology 202(1-2): 211-229, DOI 10.1016/j.sedgeo.2007.03.004.

Alexandrowicz SW, Klimek K, Kowalkowski A, Mamakowa K, Niedziałkowska E, Pazdur M and Starkel L, 1981. The evolution of the Wisłoka valley near Dębica during the Late Glacial and Holocene. Folia Quaternaria 53: 91pp.

Anderson E, Harrison S, Passmore DG, Mighall TM and Wathan S, 2004. Late Quaternary river terrace development in the Macgillycuddy's Reeks, southwest Ireland. Quaternary Science Reviews 23(16-17): 1785-1801, DOI 10.1016/j.quascirev.2003.12.001.

Ashley GM and Hamilton TD, 1993. Fluvial response to Late Quaternary climatic fluctuations, central Kobuk valley, northwestern Alaska. Journal of Sedimentary Petrology 63(5): 814-827.

Bałaga K, 1998. Post-glacial vegetational changes in the Middle Roztocze (E Poland). Acta Palaeobotanica 38(1): 175-192.

Benito G, Sopeña A, Sánchez-Moya Y, Machado MJ and PérezGonzález A, 2003. Palaeoflood record of the Tagus River (Central Spain) during the Late Pleistocene and Holocene. Quaternary Science Reviews 22(15-17): 1737-1756, DOI 10.1016/S02773791(03)00133-1.

Berendsen HJA and Stouthamer E, 2002. Paleogeographic evolution and avulsion history of the Holocene Rhine-Meuse delta, The Netherlands. Geologie en Mijnbouw 81(1): 97-112.

Bhattacharya JP and Giosan L, 2003. Wave-influenced deltas: geomorphological implications for facies reconstruction. Sedimentology 50 (1): 187-210, DOI 10.1046/j.1365-3091.2003.00545.x.

Bluszcz A, Poręba GJ and Śnieszko Z, 2007. The basis of the study of the age of the Holocene diluvium on loess areas of Polish Highlands. Geochronometria 28: 61-66, DOI 10.2478/v10003-0070022-1.

Bohncke SJP and Vandenberghe J, 1991. Palaeohydrological development in the Southern Netherlands during the last 15000 years. In: Starkel L, Gregory KJ, Thornes JB, eds., Temperate palaeohydrology. Chichester, John Wiley \& Sons: 253-281.

Crouzet C, Nicoud G, Fudral S, Rampnoux JP, Dzikowski M, Paillet A and Lacombe P, 1999. Contrôle du remplissage détritique tardiglaciaire à holocène d'une haute vallée alpine par les dynamiques de versant : l'exemple de la moyenne Maurienne (Savoie) (Late glacial Holocene infill in a high alpine valley: The Maurienne valley (Savoie)). Quaternaire 10(1): 37-48 (in French).

Friele PA, Clague JJ, Simpson K and Stasiuk M, 2005. Impact of a Quaternary volcano on Holocene sedimentation in Lillooet River valley, British Columbia. Sedimentary Geology 176(3-4): 305-322, DOI 10.1016/j.sedgeo.2005.01.011.

Gębica P, 1995. Ewolucja doliny Wisty pomiędzy Nowym Brzeskiem a Opatowcem $w$ vistulianie $i$ holocenie (Evolution of the Vistula River valley between Nowe Brzesko and Opatowiec in the Vistulian and Holocene). Dokumentacja Geograficzna 2: 5-91 (in Polish).

Godłowska M, Starkel L and Wasylikowa K, 1988. Environmental changes in the Neolithic in the light of the Pleszów site. In: Starkel L, Rutkowski J and Ralska-Jasiewiczowa M, eds, Lateglacial and Holocene environmental changes. Excursion Guide Book - Symposium Vistula Basin, Cracow, 15-21 June 1988: 52-56.

Harmata K, 1987. Late-glacial and Holocene history of vegetation at Roztoki and Tarnowiec near Jasło (Jasło-Sanok Depression). Acta Palaeobotanica 27(1): 43-65.

Harmata K, 1995. A Late Glacial and early Holocene profile from Jasło and a recapitulation of the studies on the vegetational history of the Jasło-Sanok Depression in the last 13000 years. Acta Palaeobotanica 35(1): 15-45.

Heap AD, Bryce S and Ryan DA, 2004. Facies evolution of Holocene estuaries and deltas: a large-sample statistical study from Australia. Sedimentary Geology 168(1-2): 1-17, DOI 10.1016/j.sedgeo.2004.01.016.

Holliday VT, 2000. Folsom drought and episodic drying on the Southern High Plains from 10,900-10,200 ${ }^{14} \mathrm{C}$ yr B.P. Quaternary Research 53(1): 1-12, DOI 10.1006/qres.1999.2089.

Holmes PJ, Boardman J, Parsons AJ, Marker ME, 2003. Geomorphological palaeoenvironments of the Sneeuberg Range, Great Karoo, South Africa. Journal of Quaternary Science 18(8): 801-813, DOI 10.1002/jqs.799.

Jahn A, 1955. Dolina Kłodnicy i stratygrafia utworów plejstoceńskich pod Gliwicami (Górny Śląsk) (The Kłodnica valley and stratigraphy of Pleistocene deposits at Gliwice (Upper Silesia)). Biuletyn Państwowego Instytutu Geologicznego 97: 311-330 (in Polish).

Jersak J, Sendobry K and Śnieszko Z, 1992. Postwarciańska ewolucja wyżyn lessowych w Polsce (Evolution of loess covers in Poland during the post-Warta period). Katowice, Silesian University Press: 198pp (in Polish). 
Kalicki T, 1991. The evolution of the Vistula river valley between Cracow and Niepołomice in late Vistulian and Holocene times. In: Starkel L, ed., Evolution of the Vistula River valley during the last 15000 years. Part IV. Geographical Studies, Special Issue 6: 11-37.

Kalicki T, 1996. Overbank deposits as indicators of the changes in discharges and supply of sediments in the upper Vistula valley the role of climate and human impact. In: Starkel L, ed, Evolution of the Vistula River valley during the last 15000 years. Part VI. Geographical Studies, Special Issue 9: 43-60.

Kalicki T, 2006. Zapis zmian klimatu oraz działalności człowieka i ich rola $w$ holoceńskiej ewolucji dolin środkowoeuropejskich (Reflection of climatic changes and human activity and their role in the Holocene evolution of Central European valleys). Prace Geograficzne 204: 5-348.

Kalicki T and Zernickaya VP, 1995. Paleogeography of the Vistula valley near Cracow based on sediments and palynology of the Allerød paleochannel fill. In: Starkel L, ed., Evolution of the Vistula River valley during the last 15000 years. Part V. Geographical Studies, Special Issue 8: 9-18.

Kamp JrU, Haserodt K and Shroder JrJF, 2004. Quaternary landscape evolution in the eastern Hindu Kush, Pakistan. Geomorphology 57(1-2): 1-27, DOI 10.1016/S0169-555X(03)00080-1.

Klimek K, 1999. A 1000 year alluvial sequence as an indicator of catchment/floodplain interaction: the Ruda valley, SubCarpathians, Poland. In: Brown AG and Quine TA, eds, Fluvial processes and environmental change. Chichester, John Wiley \& Sons: $329-344$.

Klimek K, 2002. Human-induced overbank sedimentation in the foreland of the Eastern Sudety Mountains. Earth Surface Processes and Landforms 27: 391-402.

Klimek K, 2003. Sediment transfer and storage linked to Neolithic and Early Medieval soil erosion in the Upper Odra Basin, southern Poland. In: Howard AJ, Macklin MG and Passmore DG, eds., Alluvial Archaeology in Europe. Lisse, Swets \& Zeitlinger: 251-259.

Klimek K, Łanczot M and Nogaj-Chachaj J, 2006. Historical deforestation as a cause of alluviation in small valleys, subcarpathian loess plateau, Poland. Regional Environmental Change 6(1-2): 52-61, DOI 10.1007/s10113-005-0008-3.

Kociuba W and Brzezińska-Wójcik T, 1999. Zarys paleogeografii roztoczańskiego odcinka doliny Wieprza (SE Polska) w czwartorzędzie (An outline of paleogeography of the Roztocze course of the Wieprz River valley (SE Poland) in the Quaternary). Annales Universitatatis Mariae Curie-Skłodowska 54(4): 49-82 (in Polish).

Koutaniemi L, 1987. Palaeohydrology of the rivers Ivalojoki and Oulankajoki, Finland. Fennia 165(1): 89-132.

Kozarski S, 1983. River channel adjustment to climatic change in west central Poland. In: Gregory KJ, ed., Background to palaeohydrology. Chichester, John Wiley \& Sons: 355-374.

Kozarski S and Nowaczyk B, 1999. Paleogeografia Polski w vistulianie (Palaeogeography of Poland in the Vistulian). In: Starkel L, ed., Geografia Polski. Środowisko przyrodnicze (Geography of Poland. The natural environment). Warsaw, Wydawnictwo Naukowe PWN: 79-103 (in Polish)

Kulczycka-Leciejewiczowa A, 1993. Osadnictwo neolityczne w Polsce południowo-zachodniej. Próba zarysu organizacji przestrzennej (Neolithic Settlement in South-Western Poland. An Outline of Spatial Organization). Wrocław, Instytut Archeologii i Etnologii PAN: 223pp (in Polish).

Lewin J and Macklin MG, 2003. Preservation potential for Late Quaternary river alluvium. Journal of Quaternary Science 18(2): 107120, DOI 10.1002/jqs.738.

Lewin J, Macklin MG and Johnstone E, 2005. Interpreting alluvial archives: sedimentological factors in the British Holocene fluvial record. Quaternary Science Reviews 24(16-17): 1873-1889, DOI 10.1016/j.quascirev.2005.01.009.

Li C, Wang P, Sun H, Zhang J, Fan D and Deng B, 2002. Late Quaternary incised-valley fill of the Yangtze delta (China): its stratigraphic framework and evolution. Sedimentary Geology 152(1-2): 133-158, DOI 10.1016/S0037-0738(02)00066-0.

Ludwikowska-Kędzia M, 2000. Ewolucja środkowego odcinka doliny rzeki Belnianki w późnym glacjale $\mathrm{i}$ holocenie (Evolution of the middle reach of the Belnianka River valley in the Lateglacial and Holocene). Warsaw, Wydawnictwo Akademickie Dialog: 181pp (in Polish)

Łajczak A, 1995. Potential rates of the present-day overbank sedimentation in the Vistula valley at the Carpathian Foreland, southern Poland. Quaestiones Geographicae 17/18: 41-53.
Macaire JJ, Bernard J, Di-Giovanni C, Hinschberger F, LimondinLozouet $\mathrm{N}$ and Visset L, 2006. Quantification and regulation of organic and mineral sedimentation in a late-Holocene floodplain as a result of climatic and human impacts (Taligny marsh, Parisian Basin, France). The Holocene 16(5): 647-660, DOI 10.1191/0959683606hl961rp.

Macklin MB, Benito G, Gregory KJ, Johnstone E, Lewin E, Michczyńska DJ, Soja R, Starkel L and Thorndycraft VR, 2006. Past hydrological events reflected in the Holocene fluvial record of Europe. Catena 66(1-2): 145-154, DOI 10.1016/j.catena.2005.07.015.

Magny M, 2004. Holocene climate variability as reflected by midEuropean lake-level fluctuations and its probable impact on prehistoric human settlements. Quaternary International 113(1): 65-79, DOI 10.1016/S1040-6182(03)00080-6.

Magny M, Leuzinger U, Bortenschlager S and Hass JN, 2006. Tripartite climate reversal in Central Europe 5600-5300 years ago. Quaternary Research 65(1): 3-19, DOI 10.1016/j.yqres.2005.06.009.

Malik I, 2008. Dating of small gully formation and establishing erosion rates in old gullies under forest by means of anatomical changes in exposed tree roots (Southern Poland). Geomorphology 93(3-4): 421-436, DOI 10.1016/j.geomorph.2007.03.007.

Malik JN, Khadkikar AS and Merh SS, 1999. Allogenic control on late Quaternary continental sedimentation in the Mahi River basin, western India. Journal of the Geological Society of India 53(3): 299-314.

Mamakowa K, 1970. Late Glacial and Holocene vegetation from the territory of Cracow. Acta Palaeobotanica 11(1): 3-12.

Mangerud J, Andersen ST, Berglund BE and Donner JJ, 1974. Quaternary stratigraphy of Norden, a proposal for terminology and classification. Boreas 3: 109-128.

Matoshko AV, Gozhik PF and Ivchenko AS, 2002. The fluvial archive of the Middle and Lower Dnieper (a review). Geologie en Mijnbouw 81(3-4): 339-355.

Melis MI and Acworth RI, 2001. An aeolian component in Pleistocene and Holocene valley aggradation - evidence from Dicks Creek catchment, Yass, New South Wales. Australian Journal of Soil Research 39(1): 13-38, DOI 10.1071/SR99099.

Michno A, 2004. Transformacja doliny dolnej Nidzicy w holocenie (The development of the Lower Nidzica River Valley during the Holocene Age). Cracow, Institute of Geography and Spatial Management of the Jagiellonian University: 97pp (in Polish).

Mierzwiński A, 1994. Przemiany osadnicze społeczności kultury łużyckiej na Śląsku (Settlement transformation of Lusatian culture community on Silesia). Wrocław, Instytut Archeologii i Etnologii PAN: 193pp (in Polish).

Morozova GS and Smith ND, 2003. Organic-rich deposition in the Saskatchewan River floodplain (Cumberland Marshes, Canada): effects of progradational avulsions. Sedimentary Geology 157(12): 15-29, DOI 10.1016/S0037-0738(02)00192-6.

Niedziałkowska E, Skubisz A and Starkel L, 1977. Lithology of the Eoand Meso-Holocene alluvia in Podgrodzie upon Wisłoka river. Studia Geomorphologica Carpatho-Balcanica 11: 89-100.

Niedziałkowska E, Gilot E, Pazdur M and Szczepańska K, 1985. The evolution of the Upper Vistula valley in the region of Drogomyśl in the upper Vistulian and Holocene. Folia Quaternaria 56: 101-132.

Nikitina DL, Pizzuto JE, Martin RE and Hippensteel SP, 2003. Transgressive valley-fill stratigraphy and sea-level history of the Leipsic River, Bombay Hook National Wildlife Refuge, Delaware, U.S.A. In: Olson $\mathrm{HC}$ and Leckie RM, eds, Micropaleontologic proxies for sea-level change and stratigraphic discontinuities. Society for Sedimentary Geology, Special Publication 75: 51-62.

Nita M and Wójcicki K, 2005. Record of Holocene vegetation changes against a background of environmental conditions in the Kłodnica valley (southern Poland). Quaestiones Geographicae 24: 63-73.

Panic I, 1992. Historia osadnictwa w księstwie opolskim we wczesnym średniowieczu (The history of the settlement in the Opole Duchy in the early Middle Ages). Katowice, Dissertations and studies of the Silesian Museum: 196pp (in Polish).

Podziat hydrograficzny Polski (Hydrographical subdivision of Poland), 1980. Map 1:200000. Warszawa, Institute of Meteorology and Water Management (in Polish).

Ralska-Jasiewiczowa M, 1999. Ewolucja szaty roślinnej (Evolution of vegetation). In: Starkel L, ed, Geografia Polski. Srodowisko przyrodnicze (Geography of Poland. The natural environment). Warsaw, Wydawnictwo Naukowe PWN: 105-127 (in Polish).

Ralska-Jasiewiczowa M, Starkel L, 1988. Record of the hydrological changes during the Holocene in the lake, mire and fluvial deposits of Poland. Folia Quaternaria 57: 91-127. 
Rose J, Turner C, Coope GR and Bryan MD, 1980. Channel changes in a lowland river catchment over the last 13,000 years. In: Cullingford RA, Davidson DA and Lewin J, eds, Timescales in Geomorphology. Chichester, John Willey \& Sons: 159-175.

Rotnicki K, 1991. Retrodiction of palaeodischarges of meandering and sinuous alluvial rivers and its palaeohydroclimatic implications. In: Starkel L, Gregory KJ, Thornes JB, eds, Temperate palaeohydrology. Chichester, John Willey \& Sons: 431-471.

Rotnicki K and Młynarczyk Z, 1989. Późnovistuliańskie i holoceńskie formy i osady korytowe środkowej Prosny i ich paleohydrologiczna interpretacja (Late Vistulian and Holocene channel forms and deposits of the middle Prosna River and their paleohydrological interpretation). Seria Geografia 43: 76pp (in Polish).

Rutkowski J, 1987. Vistula river valley in the Cracow Gate during the Holocene. In: Starkel L, ed., Evolution of the Vistula River valley during the last 15000 years. Part II. Geographical Studies, Special Issue 4: 31-50.

Rybníček K and Rybníčkova E, 1987. Palaeogeobotanical evidence of middle Holocene stratigraphic hiatuses in Czechoslovakia and their explanation. Folia Geobotanica et Phytotaxonomica 22(3): 313-327.

Schrott L, Hufschmidt G, Hankammer M, Hoffmann T and Dikau R, 2003. Spatial distribution of sediment storage types and quantification of valley fill deposits in an alpine basin, Reintal, Bavarian Alps, Germany. Geomorphology 55(1-4): 45-63, DOI 10.1016/S0169-555X(03)00131-4.

Schumm SA, 1968. River adjustment to altered hydrologic regimen Murrumbidgee River and Palaeochannels, Australia. United States Geological Survey Professional Paper 598: 65pp.

Schumm SA, 1977. The fluvial system. Chichester, John Willey \& Sons: 338pp.

Smith DN, Roseff R, Bevan L, Brown AG, Butler S, Hughes G and Monckton A, 2005. Archaeological and environmental investigations of a Lateglacial and Holocene river sedimentary sequence on the River Soar at Croft, Leicestershire, UK. The Holocene 15(3): 353-377, DOI 10.1191/0959683605hl806rp.

Starkel L, 2001. Historia doliny Wisły od ostatniego zlodowacenia do dziś (Evolution of the Vistula River valley since the last glaciation till present). Polish Academy of Sciences, Monographies 2: 263pp (in Polish).

Starkel L, 2003. Younger Dryas-Preboreal transition documented in the fluvial environment of Polish rivers. Global and Planetary Change 35(1-2): 157-167, DOI 10.1016/S0921-8181(02)00133-9.

Starkel L, Gębica P, Kalicki T, Ludwikowska M and Niedziałkowska E, 1999. Chronostratygrafia aluwiów i form fluwialnych w południowej Polsce (Chronostratigraphy of alluvia and fluvial forms in southern Poland). In: Pazdur A, Bluszcz A, Stankowski W and Starkel L, eds., Geochronologia górnego czwartorzędu Polski w świetle datowania radioweglowego $i$ luminescencyjnego (Geochronology of the Upper Quaternary in Poland in the light of radiocarbon and luminescence dating). Wrocław: 133-155 (in Polish).

Starkel L, Soja R and Michczyńska DJ, 2006. Past hydrological events reflected in Holocene history of Polish rivers. Catena 66(1-2): 2433, DOI 10.1016/j.catena.2005.07.008

Szczepanek K, 1982. Development of the peat-bog at Słopiec and the vegetational history of the Swiętokrzyskie (Holy Cross) Mts in the last 10000 years. Acta Palaeobotanica 22(1): 117-130.

Szumański A, 1986. Postglacjalna ewolucja i mechanizm transformacji dna doliny Dolnego Sanu (Late Glacial evolution and mechanism of transformation of a floor of the Lower San Valley). Geologia 12(1): 92pp (in Polish).
Szumański A and Starkel L, 1990. Channel pattern changes and attempts to reconstruct the hydrological changes. In: Starkel L, ed., Evolution of the Vistula River valley during the last 15000 years. Part III. Geographical Studies, Special Issue 5: 154-163.

Szwarczewski P, 2007. Geomorfologiczne skutki zasiedlenia wysoczyzn lessowych na przykładzie okolic Chrobrza (Ponidzie Pińczowskie) (Geomorphological response to settlement on loess plateau - Chroberz area (Ponidzie Pińczowskie) case study). In: Smolska E and Giriat D, eds, Rekonstrukcja dynamiki procesów geomorfologicznych - formy rzeźby i osady (Reconstruction of morphological processes dynamics - landforms and deposits). Warsaw, University of Warsaw: 389-397 (in Polish).

Śnieszko Z, 1995. Ewolucja obszarów lessowych Wyżyn Polskich w czasie ostatnich 15000 lat (The loess cover evolution during last 15000 years in Polish Upplands). Silesian University Press, Katowice: $124 \mathrm{pp}$ (in Polish).

Snieszko Z and Grygierczyk S, 1991. Osady kopalnej bruzdy w Bronocicach i ich związek z działalnością człowieka w neolicie (Mineral sediments of furrows in Bronocice and their relation with man's activities in the Neolithic Period). In: Jersak J, ed, Less $i$ osady dolinne (Loess and valley deposits). Katowice, Silesian University Press: pp.129-146 (in Polish)

Ta TKO, Nguyen VL, Tateishi M, Kobayashi I, Saito Y and Nakamura T, 2002. Sediment facies and Late Holocene progradation of the Mekong River Delta in Bentre Province, southern Vietnam: an example of evolution from a tide-dominated to a tide- and wavedominated delta. Sedimentary Geology 152(3-4): 313-32, DOI 10.1016/S0037-0738(02)00098-2.

Törnqvist TE, 1994. Middle and late Holocene avulsion history of the River Rhine (Rhine-Meuse delta, Netherlands). Geology 22: 711714, DOI 10.1130/0091-7613(1994)022<0711:MALHAH $>$ 2.3.CO;2.

Wasylikowa K, Starkel L, Niedziałkowska E, Skiba S and Stworzewicz E, 1985. Environmental changes in the Vistula valley at Pleszów caused by Neolithic man. Przeglad Archeologiczny 33: 19-55.

White WA, Morton RA and Holmes CW, 2002. A comparison of factors controlling sedimentation rates and wetland loss in fluvialdeltaic systems, Texas Gulf coast. Geomorphology 44(1-2): 47-66, DOI 10.1016/S0169-555X(01)00140-4.

Wójcicki K, 2006. The oxbow sedimentary subenvironment: its value in palaeogeographical studies as illustrated by selected fluvial systems in the Upper Odra catchment, southern Poland. The Holocene 16(4): 589-603, DOI 10.1191/0959683606hl953rp.

Wójcicki K and Nita M, 2004. Dolina dolnej Kłodnicy w dobie pradziejowego i wczesnośredniowiecznego osadnictwa - zapis w formach i osadach (The valley of the Lower Kłodnica River during prehistoric and early historic settlements - the record in sedimentary forms and deposits). In: Abłamowicz D and Śnieszko Z, eds., Zmiany środowiska geograficznego $w$ dobie gospodarki rolnohodowlanej (Geographical environment changes in the period of farming and breeding economy). Katowice: 253-270 (in Polish).

Wójcik A, 1987. Late-glacial lacustrine sediments from Roztoki and Tarnowiec near Jasło (Jasło-Sanok Depression). Acta Palaeobotanica 27(1): 27-41.

Zygmunt E, 2004. Archaeological and radiocarbon dating of alluvial fans as an indicator of prehistoric colonisation of the Glubczyce Plateau (southwestern Poland). Geochronometria 23: 101-107.

Żurek S, Michczyńska DJ and Pazdur A, 2002. Time record of palaeohydrologic changes in the development of mires during the Late Glacial and Holocene, North Podlasie Lowland and Holy Cross Mts. Geochronometria 21: 109-118. 